\title{
Nanomaterial-Integrated Cellulose Platforms for Optical Sensing of Trace Metals and Anionic Species in the Environment
}

\author{
Carlos Bendicho*(D), Isela Lavilla, Francisco Pena-Pereira, Inmaculada de la Calle and Vanesa Romero \\ Centro de Investigación Mariña, Universidade de Vigo, Departamento de Química Analítica y Alimentaria, \\ Grupo QA2, 36310 Vigo, Spain; isela@uvigo.es (I.L.); fjpena@uvigo.es (F.P.-P.); incalle@uvigo.es (I.d.1.C.); \\ vromero@uvigo.es (V.R.) \\ * Correspondence: bendicho@uvigo.es; Tel.: +34-986-812281; Fax: +34-986-812556
}

check for

updates

Citation: Bendicho, C.; Lavilla, I.; Pena-Pereira, F.; de la Calle, I.;

Romero, V. Nanomaterial-Integrated Cellulose Platforms for Optical Sensing of Trace Metals and Anionic Species in the Environment. Sensors 2021, 21, 604. https://doi.org/ $10.3390 / \mathrm{s} 21020604$

Received: 22 December 2020 Accepted: 13 January 2021 Published: 16 January 2021

Publisher's Note: MDPI stays neutral with regard to jurisdictional clai$\mathrm{ms}$ in published maps and institutional affiliations.

Copyright: (C) 2021 by the authors. Licensee MDPI, Basel, Switzerland. This article is an open access article distributed under the terms and conditions of the Creative Commons Attribution (CC BY) license (https:// creativecommons.org/licenses/by/ $4.0 /)$.

\begin{abstract}
The development of disposable sensors that can be easily adapted to every analytical problem is currently a hot topic that is revolutionizing many areas of science and technology. The need for decentralized analytical measurements at real time is increasing for solving problems in areas such as environment pollution, medical diagnostic, food quality assurance, etc., requiring fast action. Despite some current limitations of these devices, such as insufficient detection capability at (ultra)trace level and risk of interferent effects due to matrix, they allow low-cost analysis, portability, low sample consumption, and fast response. In the last years, development of paper-based analytical devices has undergone a dramatic increase for on-site detection of toxic metal ions and other pollutants. Along with the great availability of cellulose substrates, the immobilization of receptors providing enhanced recognition ability, such as a variety of nanomaterials, has driven the design of novel sensing approaches. This review is aimed at describing and discussing the different possibilities arisen with the use of different nanoreceptors (e.g., plasmonic nanoparticles, quantum dots, carbon-based fluorescent nanoparticles, etc.) immobilized onto cellulose-based substrates for trace element detection, their advantages and shortcomings.
\end{abstract}

Keywords: cellulose substrates; sensors; PADs; microPADs; metal ions; anionic species; environmental samples

\section{Introduction}

Conventional analytical methodology using equipment in central labs is well established but a number of stages such as sampling, sample preparation, and optimization of instrumental parameters need to be accomplished before analytical information can be obtained. For instance, in the control of environmental pollutants, time-consuming operations such as sampling at fixed times and locations, sample preservation procedures and storing need to be typically carried out prior to analysis. Generally, centralized analytical equipment involves high acquisition and maintenance costs and besides, it requires special facilities for suitable operation and well-trained technical personnel. In addition, most atomic spectrometry techniques that are suitable for trace element analysis involve high energy and sample consumption as well as the need for gases.

Miniaturization of analytical systems plays an important role in the development of novel strategies for on-site analysis, besides contributing to decrease the reagents and samples consumption, and ultimately, energy, in agreement with the current trends of green chemistry [1]. Total analysis systems (TAS) or lab-on-chip has been a first advance in this direction [2]. The immobilization of a variety of receptors (recognition elements) on solid substrates are suitable strategies for designing novel analytical systems, as reflected in the literature. Thus, immobilization of nanomaterials based on metals and oxides on different surfaces, i.e., glass, quartz, vitreous carbon, metals, porous polymer monoliths, 
etc., is a necessary requirement for surface plasmon resonance sensors, surface enhanced Raman dispersion, electrochemistry, microextraction, analytical separations and quartz crystal microbalance sensors [3].

Implementation of biodegradable substrates such as cellulose-based materials of widespread use, has enabled the development of a large variety of microfluidic analytical systems with applications mainly for medical diagnosis [4]. Unlike lab-on-a-chip devices relying on silicon, glass, or polymers such as polydimethylxilosane (PDMS), which require complicated fabrication processes, paper-based microfluidic devices, also known as labon-a-paper, are based on cellulose-based materials. Cellulose is a biopolymer that can be found in nature, e.g., cells in wood and cotton $[5,6]$. This biopolymer is formed by linear homo-polysacaride based on D-anhidroglucopyranose units linked by beta-1-4-glycosidic bonds. In agreement with the World Health Organization (WHO), clinical diagnosis carried out with paper-based analytical devices fulfils the terms included within the acronym ASSURED (affordable, sensitive, specific, user-friendly, rapid and robust, equipment free and deliverable to end-users) [4].

At this point, it is necessary to distinguish between two main configurations in which cellulose-based analytical devices are presented, namely, paper-based microfluidic devices (microPADs) and paper-based assay devices (PADs). The first ones are formed by a fluidic network on the paper substrate where sample and reagent transport occur by capillarity. These systems have evolved from the lateral flow simple approaches up to more complex tridimensional designs. Commonly, the acronym PAD (paper-based analytical device) is employed to cover both possibilities, but in this review, both acronyms will be kept so that we can maintain the difference between them. Paper-based assays (also known in the literature as paper-based sensors or spot tests) have their origin in the old classical qualitative analysis firstly proposed by F. Feigl, where many cations and anions could be detected by different colorimetric or fluorimetric reactions. Many reactions were carried out on filter paper, taking advantage of the great porosity and adsorption ability which enables to accomplish assays with enhanced sensitivity in comparison with other substrates [7].

The interest in the development of paper-based analytical devices relies on the hydrophilic nature of the substrate, easy construction and handling, low cost, high capillarity (wicking effect), and porosity which facilitates the immobilization of receptors and analyte diffusion, disposable use, biodegradability, and biocompatibility. In addition, white color is excellent for colorimetric transduction and no external forces are required to conduct the analyte up to the detection area.

Human exposure to metal ions contributes to morbidity and mortality, particularly in countries that lack strict regulations. Likewise, some anionic species can also cause toxic effects, so their presence in waters must be controlled. To ensure water quality after purification processes in wastewater treatment plants, suitable analytical control of several parameters including several metal ions (e.g., $\mathrm{Cd}, \mathrm{Cu}, \mathrm{Cr}, \mathrm{Hg}, \mathrm{Pb}, \mathrm{Ni}, \mathrm{Zn}$, and $\mathrm{As}$ ) as well as anions (chloride, sulphate, nitrate, nitrite, sulphide, iodide, fluoride, cyanide, etc.) is required [8]. Drinking water regulations also include maximum concentration levels for several metal ions and anions, which cause harmful effects on environment and health [9-11]. The different guidelines show the need for very sensitive techniques for successful detection in drinking water in the range of ppm-ppb. Despite the abovementioned advantages accounting for the sharp increase in the development of PADs and microPADs for determining trace element analysis in environmental samples, lack of enough sensitivity to fulfil most drinking water guidelines is a main drawback, something that could be alleviated by further progress in three areas (Figure 1), i.e., introduction of receptors providing enhanced response (e.g., nanostructured receptors), optimized designs, and integration with preconcentration approaches, as will be discussed in this review. 


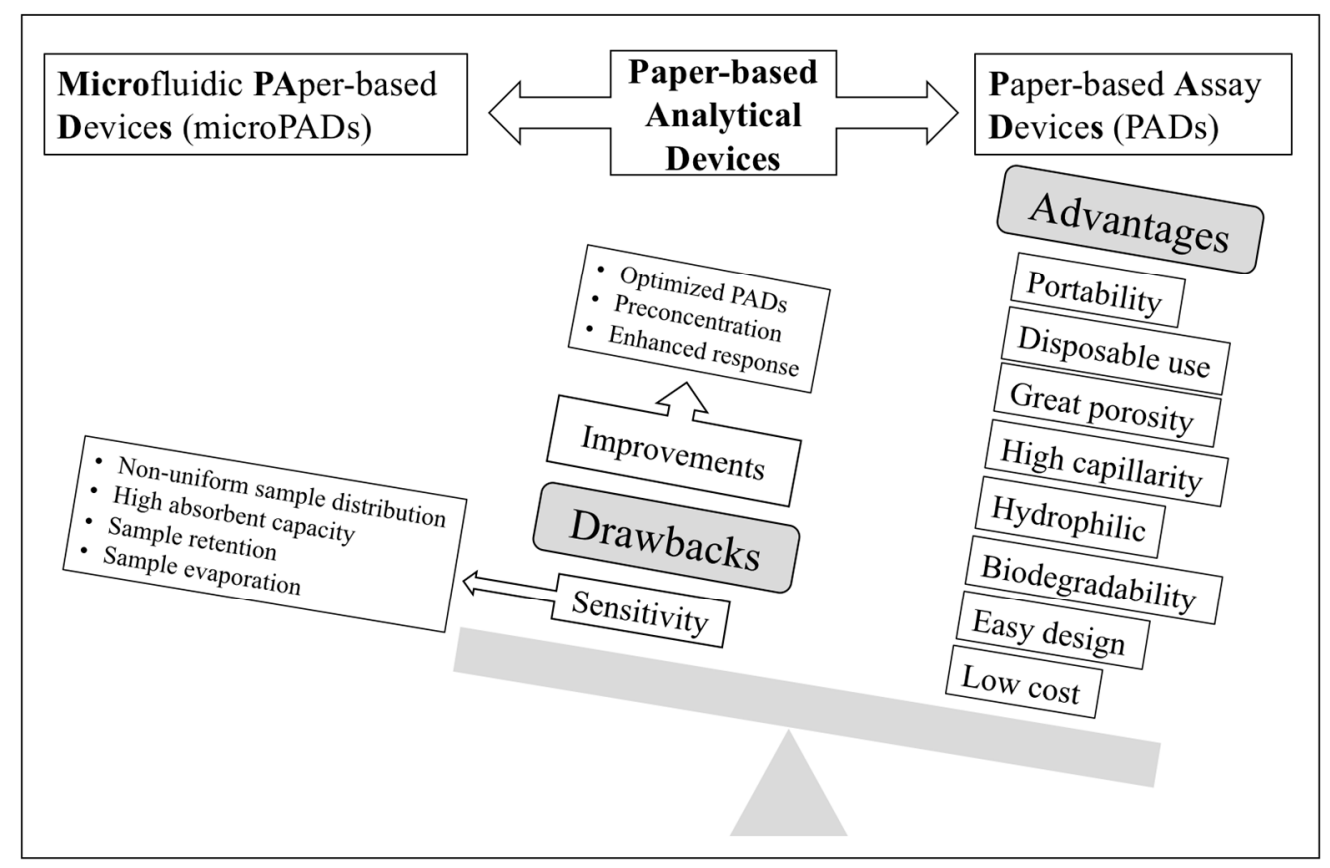

Figure 1. Schematic diagram showing the advantages and drawbacks of paper-based analytical devices as well as possible pathways for enhancing sensitivity.

The combination of paper-based analytical devices with information and communication technologies (ICTs) such as smartphones, scanners, digital cameras, etc., can drive the design of green, miniaturized, low cost, and easy-to-use technologies for detection of elemental species.

The role played by paper-based analytical devices as sensing platforms for trace elements using different transduction systems has been discussed in both general reviews [12-21] and specific reviews [22-24] published in recent years. However, no review has addressed the new design of paper-based assay devices where instead of conventional receptors (i.e., chemoreceptors), a variety of nanostructured materials with unique optical properties such as plasmonic nanoparticles (NPs) (e.g., AgNPs and AuNPs), fluorescent nanoparticles (e.g., quantum dots, carbon quantum dots, graphene quantum dots, etc.), and other hybrid materials are implemented. In addition, new sensing approaches that integrate a PAD with a separation/preconcentration technique have arisen during the last few years. Figure 2 shows the percentage of applications reported for metal ions and anions using PADs and microPADs mainly in the environmental field.

In the first part of this review, the state-the-of-art of PADs and microPADs for optical detection (colorimetry and luminescence) of metal ions and anionic species using both traditional chromogenic reagents and nanostructured receptors for analyte recognition is addressed. In the second part, several PADs integrated with preconcentration techniques for improving selectivity and sensitivity are discussed. 


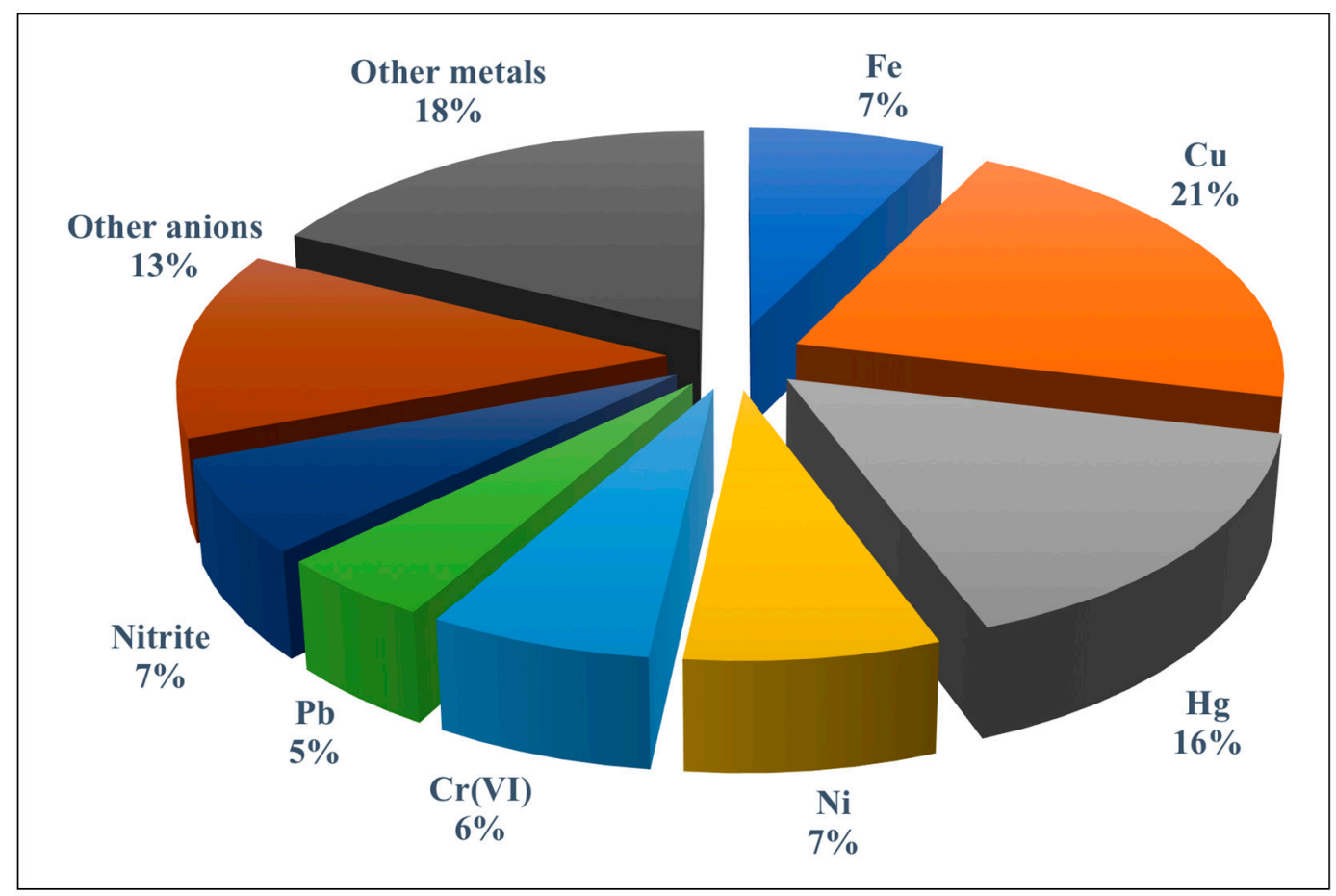

Figure 2. Percentage of publications dealing with paper-based assay devices (PADs) and microfluidic paper-based devices (microPADs) for the detection of trace metals and anions. The group of other metals includes $\mathrm{Mn}, \mathrm{Zn}, \mathrm{Ag}, \mathrm{Se}, \mathrm{Cd}, \mathrm{Co}, \mathrm{Ce}, \mathrm{Al}$, and As; the group of other anions includes iodate, iodide, cyanide, fluoride, sulphate, sulphite, chloride, and sulphide.

\section{Detection of Metal Ions and Anionic Species by Paper-Based Analytical Devices along with Chromogenic/Fluorogenic Reagents}

Most applications reported for the detection of trace metals and anions using chromogenic/fluorogenic receptors has mainly been performed with different types of microPADs (i.e., 2D, 3D, and distance-based).

In microPADs designed for the detection of metal species, analytes are driven by capillary action to a detection area where the recognition event takes place. Colorimetric detection has been typically carried out using a chromogenic reagent such as a complexing agent, giving rise to the formation of metal-ligand colored complexes. The microPADs require hydrophobic barriers to be printed on the substrate to direct the flow. The suction of a liquid by a capillary pressure caused by the curvature of the meniscus is a fundamental mechanism that explains the two-phase flow in porous media. The flow in these systems is laminar because of the size $<20 \mu \mathrm{m}$ of fibers and pores associated, resulting in low Reynolds' numbers. In the modeling of these flows, the law of Darcy and the equation of Lucas-Washburn are fulfilled under certain premises [21]. Different techniques such as ink printing, wax printing, serigraphic printing, or even the use of a marker of permanent ink, among others, have been used for printing the hydrophobic barriers [24].

Representative applications of PADs and microPADs both using chromogenic/fluorogenic reagents [25-44] and nanostructured materials [45-55] for the detection of metal ions in environmental samples are shown in Table 1. 
Table 1. Applications of colorimetric detection of metal ions using PADs and $\mu$ PADs along with chromogenic/fluorogenic and nanostructured receptors.

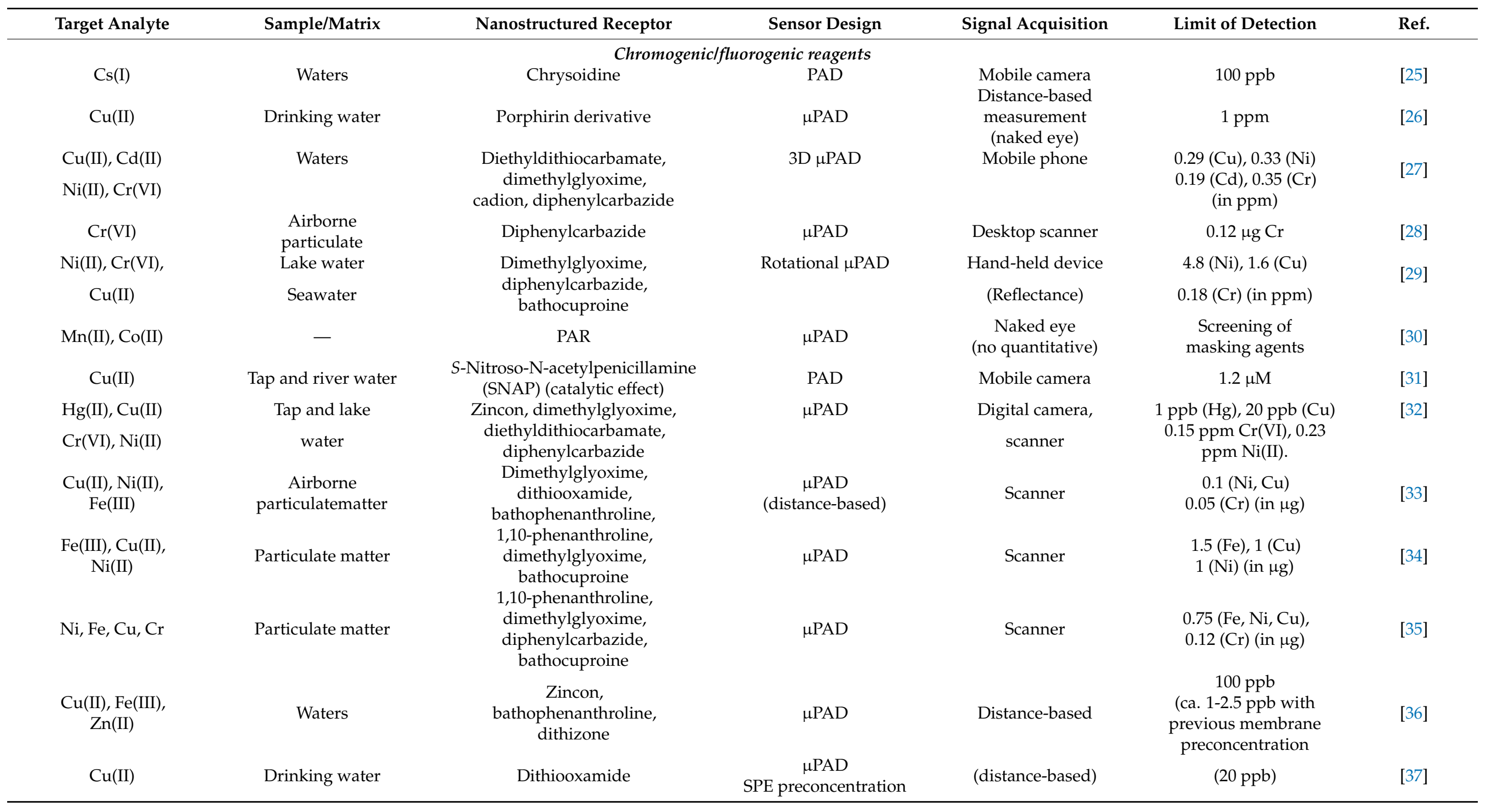


Table 1. Cont.

\begin{tabular}{|c|c|c|c|c|c|c|}
\hline Target Analyte & Sample/Matrix & Nanostructured Receptor & Sensor Design & Signal Acquisition & Limit of Detection & Ref. \\
\hline $\mathrm{Cu}(\mathrm{II})$ & Rain and tap water & $\begin{array}{l}\text { Chrome azurol S and } \\
\text { pyrocatechol violet }\end{array}$ & $3 \mathrm{D} \mu \mathrm{PAD}$ & Scanner & 1.7 and 1.9 ppm, resp. & {$[38]$} \\
\hline $\mathrm{Cr}(\mathrm{VI})$ & Tap water & 1,5-difenylcarbazide & PAD (SH-CAT) & Scanner & 0.05 ppm Cr(VI) & [39] \\
\hline $\begin{array}{c}\text { BSA, glucose } \\
\text { Pb(II) }\end{array}$ & $\begin{array}{l}\text { Drinking water, } \\
\text { tap water, } \\
\text { wastewater }\end{array}$ & Sodium rhodizonate & $\mu \mathrm{PAD}$ & Smartphone, scanner & $10 \mathrm{ppb} \mathrm{Pb}$ & {$[41]$} \\
\hline $\mathrm{Hg}(\mathrm{II})$ & - & $\operatorname{Ir}(\mathrm{III})$ complex & PAD & Naked eye & $1.88 \times 10^{-3} \mathrm{M}$ & [43] \\
\hline B(III) & $\begin{array}{l}\text { Wastewater, } \\
\text { Seawater }\end{array}$ & $\begin{array}{c}\text { Curcumin, } \\
\text { Curcumin Longa L. extracts }\end{array}$ & PAD & $\begin{array}{l}\text { Scanner, tablet } \\
\text { camera }\end{array}$ & $\begin{array}{c}\text { 0.2-0.8 ppm } \\
\text { (depending on PAD) }\end{array}$ & {$[44]$} \\
\hline \multicolumn{7}{|c|}{ Nanostructured receptors } \\
\hline $\mathrm{Cr}(\mathrm{VI})$ & River water & BSA capped-AuNPs & $\begin{array}{l}\text { Silanization- } \mathrm{TiO}_{2} \\
\text { Modified paper }\end{array}$ & Scanner & $280 \mathrm{nM}$ & {$[45]$} \\
\hline $\mathrm{Cu}(\mathrm{II})$ & $\begin{array}{l}\text { Pond, tap water } \\
\mathrm{Hg}(\mathrm{II})\end{array}$ & $\begin{array}{c}\text { AgNPs } \\
\text { Pond, river water }\end{array}$ & $\begin{array}{l}\text { PAD and } \mu \text { PAD } \\
\text { AuNPs PAD }\end{array}$ & $\begin{array}{l}\text { Digital camera, } \\
\text { smartphone }\end{array}$ & $\begin{array}{l}0.5 \mathrm{ppb} \mathrm{Cu} \\
50 \mathrm{nM}\end{array}$ & {$[46][47]$} \\
\hline $\mathrm{Hg}(\mathrm{II})$ & Pond and tap water & PtNPs and TMB & PAD & $\begin{array}{l}\text { Digital camera and } \\
\text { smartphone }\end{array}$ & $0.01 \mu \mathrm{M}$ & [48] \\
\hline $\mathrm{Hg}(\mathrm{II})$ & Waters & Curcumin NPs & PAD & Digital camera & $\begin{array}{l}0.17 \text { ppm (direct) } \\
0.003 \text { ppm (Prec.) }\end{array}$ & [49] \\
\hline $\mathrm{Hg}(\mathrm{II}), \mathrm{NH}_{3}$ & - & AgNPs (phytosynthesis) & PAD & $\begin{array}{l}\text { Photometry and } \\
\text { naked eye }\end{array}$ & $\begin{array}{c}5 \mathrm{ppb} \mathrm{Hg}, 5 \mathrm{ppm} \mathrm{NH} \\
\text { (Photometry), } 5 \mathrm{ppm} \\
\text { (naked eye) }\end{array}$ & {$[50]$} \\
\hline $\mathrm{Ni}(\mathrm{II})$ & $\begin{array}{l}\text { River water } \\
\text { Tap water }\end{array}$ & Zincon- $\mathrm{ZnSiO}_{3}$ nanospheres & PAD & Scanner & $36 \mathrm{nM} \mathrm{Ni}$ & [51] \\
\hline $\mathrm{Fe}(\mathrm{III})$ & Water, blood & AgNPs-CTAB & PAD & Smartphone & $20 \mathrm{ppb} \mathrm{Fe}$ & [52] \\
\hline $\begin{array}{c}\operatorname{Ag}(\mathrm{I}), \mathrm{Cu}(\mathrm{II}) \\
\operatorname{Hg}(\mathrm{II})\end{array}$ & Water & ZnSe nanocrystals & PAD & Mobile camera & $\begin{array}{c}1 \mathrm{ppm}(\mathrm{Cu}) \\
5 \mathrm{ppm}(\mathrm{Hg}, \mathrm{Ag})\end{array}$ & [53] \\
\hline $\mathrm{Pb}(\mathrm{II}), \mathrm{Cu}(\mathrm{II})$ & Waters & AuNPs-TA-DNS & $\mu \mathrm{PAD}$ & Naked eye & $>10 \mathrm{ppb}$ & [54] \\
\hline $\mathrm{Cu}(\mathrm{II})$ & River water & $\mathrm{ZnO} / \mathrm{ZnS}$ core shell NPs & PAD & Digital camera & $15 \mu \mathrm{M}$ & [55] \\
\hline
\end{tabular}


In the last years, different chromogenic reagents such as $\mathrm{Cs}(\mathrm{I})$-chrysoidine [25], $\mathrm{Cu}(\mathrm{II})$ porphyrin derivative [26], $\mathrm{Cu}$ (II)-diethyldithiocarbamate [27], $\mathrm{Cd}$ (II)-cadion [27], $\mathrm{Ni}$ (II)dimethylglyoxime [27], Cr-diphenylcarbazide [27,28], $\mathrm{Cu}$ (II)-bathocuproine [29], etc., have been proposed. The use of nonselective receptors such as 4-(2-pyridylazo) resorcinol (PAR) for the detection of elements like $\mathrm{Mn}$ (II) and $\mathrm{Co}(\mathrm{II})$ requires masking strategies for improving the selectivity [30]. The catalytic effect caused by $\mathrm{Cu}(\mathrm{II})$ on the decomposition of S-nitrosothiols (RSNO) brings about a color change, which can be used for colorimetric sensing of this metal ion onto a PAD by means of a smartphone [31].

Chromogenic reagents such as Zincon, dimethylglyoxime, diethyldithiocarbamate, and diphenylcarbazide have been employed in a microPAD for the multiplexed determination of $\mathrm{Hg}(\mathrm{II}), \mathrm{Ni}(\mathrm{II}), \mathrm{Cu}(\mathrm{II})$, and $\mathrm{Cr}(\mathrm{VI})$ in waters [32] (Figure 3A). Multiplexed determination of $\mathrm{Ni}(\mathrm{II}), \mathrm{Cu}(\mathrm{II})$, and $\mathrm{Fe}(\mathrm{III})$ using a microPAD with distance-based detection has also been reported [33].

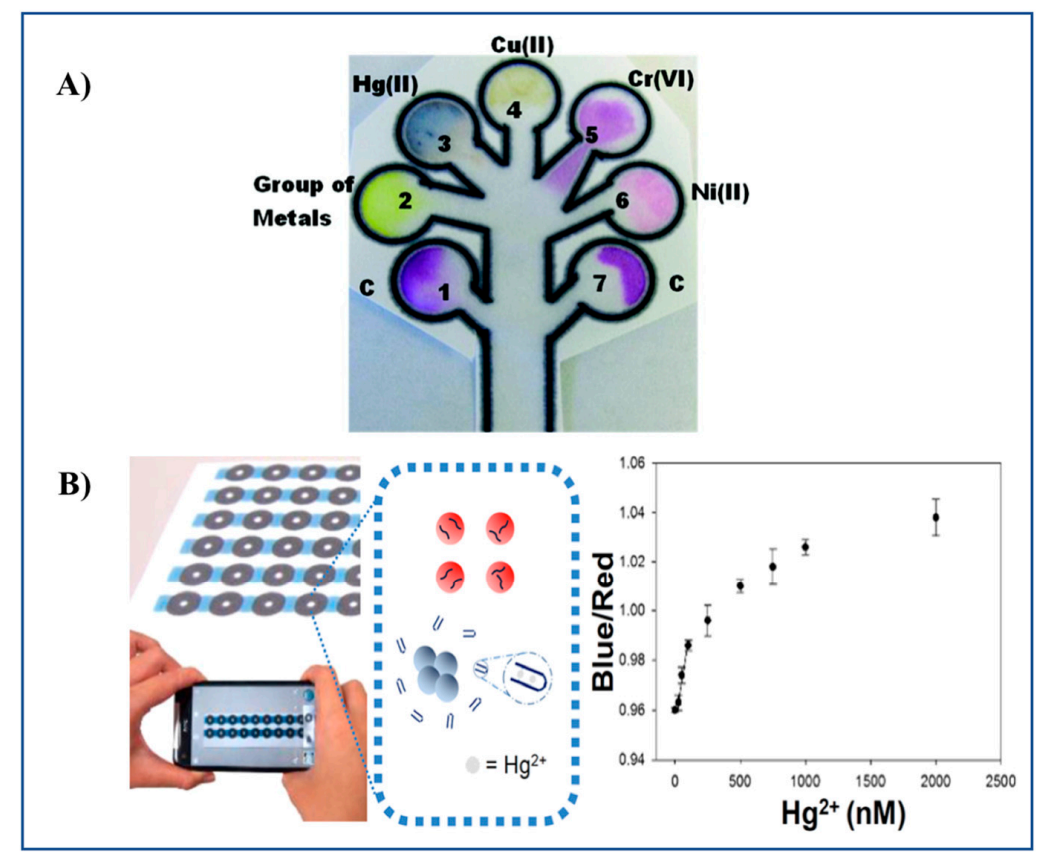

Figure 3. Representative examples of a microPAD and a PAD. (A) 2D microPAD for multiplexed detection of $\mathrm{Hg}(\mathrm{II}), \mathrm{Cu}(\mathrm{II}), \mathrm{Cr}(\mathrm{VI})$, and $\mathrm{Ni}(\mathrm{II})$ using Zincon, sodium diethyldithiocarbamate, 1,5diphenylcarbazide and dimethylglyoxime as chromogenic reagents, respectively. The microPAD was employed to detect individual metal ions or a mixture of metal ions on the basis of an enzyme-based assay ( $\beta$-galactosidase) [32]. (B) Detection of $\mathrm{Hg}$ (II) ions by a PAD based on the aggregation of ssDNA-attached AuNPs [47]. Figure 3A,B reproduced with permission of the American Chemical Society [32,47].

The limit of detection (LOD) for metal ions in waters achieved with these sensing approaches depends on the paper thickness, detection mechanism, kind of receptor, and size of channels in the microPAD [24].

A few PADs have been reported so far for the detection of anionic species. Nitrite has received much attention, for instance using the Griess reaction [56-58], tetrazine-based chemistry [59], and a modified Griess reaction [60]. Nitrate can be easily determined prior to reduction to nitrite followed by the Griess reaction in the PAD [56] (Figure 4A). Fluoride has been determined by means of two probes (namely, probe I and probe II) based on the cleavage of the Si-O bond induced by this anion [61] (Figure 4B). With probe I it is possible to recognize fluorides in the safety level in drinking water (1 ppm), while probe II enables to establish dangerous high levels in water (4 ppm). Sulphate in the form of hydrogen sulphate $\left(\mathrm{HSO}_{4}^{-}\right)$was determined taking advantage of the amphiphilic properties of this species using covalently anchored rhodamine onto a cellulose surface [62]. 
A microPAD was described recently by Duangdeewong et al. [63] for the determination of iodate in table salt and irrigation water. Oxidation of hydroxylamine by iodate to yield nitrite which in turn reacts with the Griess reagent is used for sensing. The color is captured with a digital camera giving rise to a LOD of $38.1 \mathrm{ppm}$ with a relative standard deviation (RSD) less than $2 \%$.

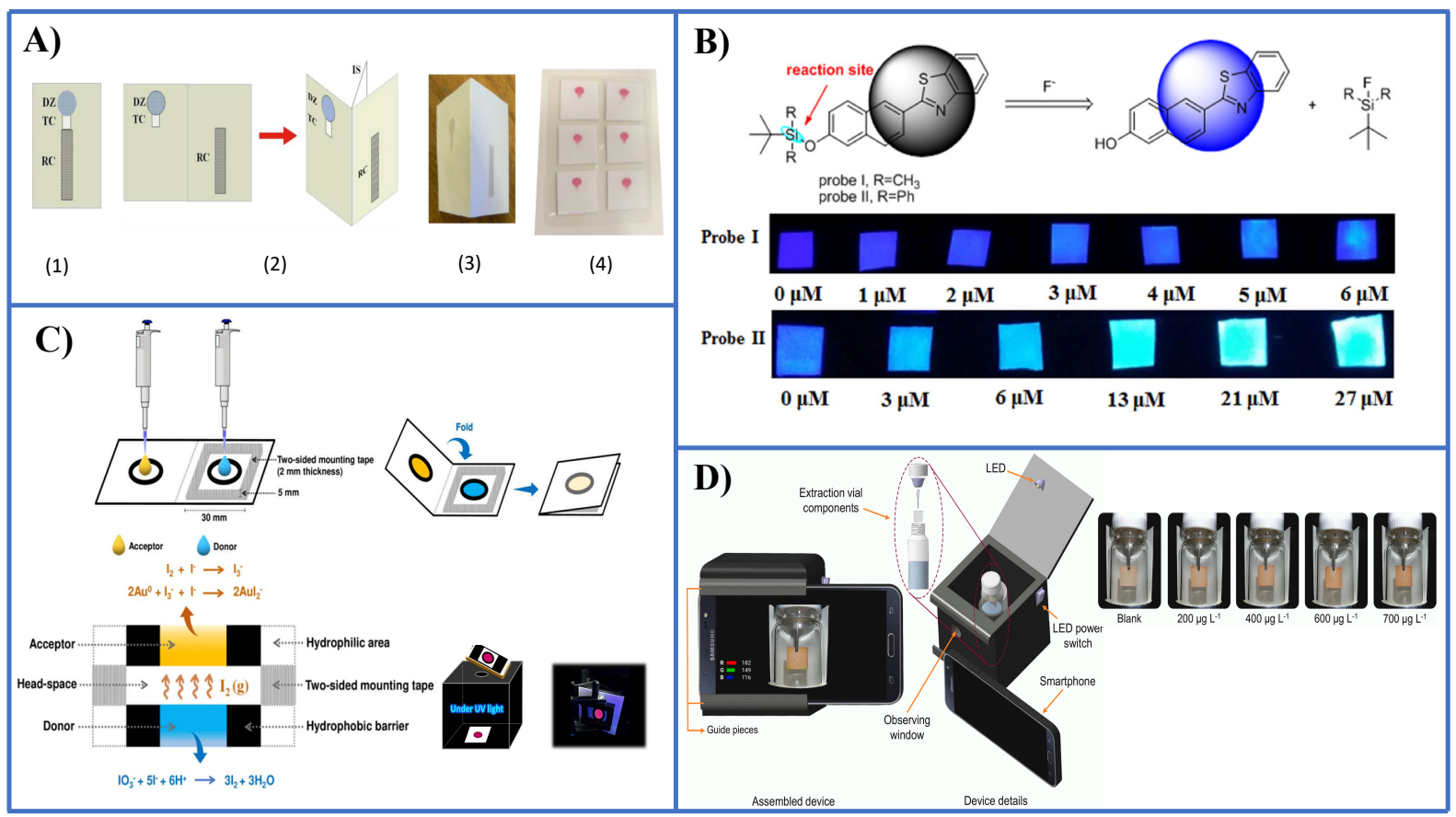

Figure 4. Representative examples of PADs and microPADS for the detection of anions. (A) Schematic diagrams showing 2D (sub-figure 1) and 3D (sub-figures 2,3) microPADs for the detection of nitrite and nitrate. Sub-figure 4 shows a card with six 3D microPADs following detection of nitrite with the Griess reagent. Nitrate was measured after conversion into nitrite with $\mathrm{Zn}$ microparticles immobilized in an hydrophilic channel of the microPAD [56]; (B) detection of fluoride by a PAD using two ratiometric fluorescent probes based on the Si-O bond cleavage [61]; (C) iodate detection by a PAD integrated with a membraneless gas-separation device and BSA-AuNCs as sensing probes. Prior reduction of iodate to free iodine was performed [64]; (D) determination of sulphite anion by a PAD integrated in a microextraction system [65]. Figure 4A,C,D is reproduced with permission of the American Chemical Society [56] and Elsevier [64,65].

Multiplexed detection of metal ions together with other substances has also been reported. Thus, a multiplexed detection of $\mathrm{Fe}(\mathrm{III}), \mathrm{Ni}(\mathrm{II})$, and bovine serum albumin (BSA) has been described by Xiong et al. [42] A microPAD impregnated with different chromogenic reagents was employed. LODs of $0.1 \mathrm{mM}(\mathrm{Fe}), 0.5 \mathrm{mM}(\mathrm{Ni})$, and $1 \mu \mathrm{M}$ (BSA) and a repeatability below $3 \%$, were reached.

\section{Detection of Trace Metals and Anions Using Paper-Based Analytical Devices and Nanostructured Receptors}

\subsection{Plasmonic Nanoparticles Immobilized onto Cellulose Substrates}

The surface plasmon resonance (SPR) phenomenon consists of the collective oscillation of electrons located at the conduction band when some metal nanoparticles (e.g., $\mathrm{Au}, \mathrm{Ag}, \mathrm{Cu}$ ) are irradiated with light of suitable frequency. It is called local surface plasmon resonance (LSPR), when the dimensions of the metal nanoparticles are less than the wavelength of the radiation [66]. When light is of the same frequency as oscillations, the electron cloud vibrates or resonates, giving rise to absorption. The LSPR depends on size, shape, and composition of the nanoparticles (nanorods and nanoshells are more sensitive to changes in the local refractive index than nanospheres). The absorption band in the spectrum corresponding to the LSPR, is influenced by several factors, being the basis for 
plasmonic sensors. Thus, the LSPR band can be shifted when the analyte binds the surface of the nanoparticle, which causes a color change, thus allowing colorimetric detection.

Colorimetric assays using plasmonic nanoparticles instead of typical chromogenic reagents may provide enhanced sensitivity and improved detection limits. Plasmonic nanoparticles display better stability as compared to most organic dyes and more importantly, they have higher extinction coefficients, hence leading to better sensitivity.

As shown in Table 1, several kinds of nanostructured receptors including plasmonic NPs have been immobilized onto cellulose substrates to build up a paper-based analytical device. A clear trend observed in the last years when using PADs as compared to microPADs, is the implementation of nanomaterials for optical detection instead of conventional chromogenic/fluorogenic reagents.

Guo et al. [45] used silanization-titanium dioxide modified filter paper (STCP) to trap bovine serum albumin (BSA) capped AuNPs. The BSA-AuNPs anchored onto the STCP were etched by $\mathrm{Cr}(\mathrm{VI})$ in the presence of $\mathrm{HBr}$, giving rise to a visible color change. $\mathrm{Cr}(\mathrm{VI})$ does not have enough ability to oxidize Au but in the presence of bromide the potential of $\mathrm{Au}(\mathrm{I}) / \mathrm{Au}(0)$ decreased due to the formation of the $\mathrm{AuBr}_{2}{ }^{-}$complex. The etching process caused the decrease in particle size and amount of AuNPs onto the filter. The method shows high resistance to interferences with a LOD of $0.28 \mu \mathrm{M} \mathrm{Cr}(\mathrm{VI})$.

A paper-based sensor using AgNPs as receptors was used for the detection of $\mathrm{Cu}$ (II) [46]. The sensing mechanism consisted of the decrease in the surface plasmon resonance absorption peak and the formation a new red-shifted peak as a result of AgNPs aggregation that occurs when $\mathrm{Cu}(\mathrm{II})$ is present. Both PADs and $\mu$ PADs were studied, using measurements by naked eye and digital camera. Homocysteine and dithiothreitol bind AgNPs through Ag-S bonds, and then they bind to $\mathrm{Cu}(\mathrm{II})$, which in turn results in AgNPs aggregation. A change in the yellow color of AgNPs to green-brown was observed in the presence of $\mathrm{Cu}(\mathrm{II})$. The sensor was applied to the determination of $\mathrm{Cu}(\mathrm{II})$ in pond and tap water.

Chen et al. [47] developed a PAD for $\mathrm{Hg}$ (II) detection in water sources (spiked pond and river water), based on AuNPs thymine- $\mathrm{Hg}$ (II)-thymine coordination chemistry (unmodified ssDNA are used as receptors for $\mathrm{Hg}$ instead of using thiolated or fluorescentlabeled ssDNA). A LOD of $50 \mathrm{nM} \mathrm{Hg}$ can be achieved. A sensing mechanism based on AuNPs aggregation is proposed, which results in a color change from red to purple and then to blue according to the degree of AuNP aggregation. Colorimetric sensing was triggered by adding $\mathrm{NaCl}$ to the sample solution along with modified AuNPs, and deposited onto paper for color enhancement. Readout in the PADs was carried out by means of a smartphone. Images were transmitted for cloud computing (Figure 3B).

The need for increased concentrations of the plasmonic NPs in PADs in comparison with assays carried out in solution has been observed [46]. A drawback reported when immobilizing plasmonic NPs onto cellulose is the limited aggregation that may occur, which, in turn, is responsible for changes in color occurring in the presence of the analyte. In some works, the possibility of making the assay in solution with further transfer of the probe to the PAD has been tried [47].

Chen et al. [48] reported a PAD based on the oxidation of the reagent 3,3,5,5-tetramethy lbenzidine (TMB) $-\mathrm{H}_{2} \mathrm{O}_{2}$ by PtNPs that are added to the sample. PtNPs cause a fast oxidation of TMB, giving rise to a blue color. $\mathrm{Hg}(\mathrm{II})$ interact with PtNPs, inhibiting the oxidation process. The decrease of blue color occurring as a result of the presence of $\mathrm{Hg}$ (II) can be observed by naked eye. For low $\mathrm{Hg}$ (II) concentration $(0.01 \mu \mathrm{M})$, a fiber optic sensor device can be employed after capturing images by digital camera or smartphone.

Curcumin nanoparticles (CURNs) in PADs were used as receptors for selective sensing $\mathrm{Hg}$ (II) [49]. A LOD of $0.17 \mathrm{ppm}$ (without preconcentration) and $0.003 \mathrm{ppm}$ after 50 times preconcentration was obtained. The yellow color of CURNs onto paper changed to light yellow in the presence of $\mathrm{Hg}(\mathrm{II})$. The image of the test zone was captured by a digital camera and processed by Adobe photoshop CS8. A sensing mechanism based on the complex formation between $\mathrm{Hg}$ (II) and CURNs was proposed. The assay was applied to 
the determination of $\mathrm{Hg}(\mathrm{II})$ in environmental and industrial water samples. For enhancing sensitivity, repeated additions of sample onto the same test zone were performed.

A paper-based sensor for $\mathrm{Hg}$ (II) and $\mathrm{NH}_{3}$ was developed following AgNPs phytosynthesis [50]. An aqueous leaf extract of Convolvulus cneorum was used for reduction and stabilization of $\mathrm{Ag}$ (I) into AgNPs. A LOD of $5 \mathrm{ppb} \mathrm{Hg}(\mathrm{II})$ and $5 \mathrm{ppm}$ ammonia for assays carried out in solution was obtained. The sensor enabled the detection of $\mathrm{Cr}(\mathrm{VI})$ and aqueous ammonia by naked eye using the PAD. The LSPR band of AgNPs shifted to blue in the presence of $\mathrm{Hg}$ (II) and ammonia.

A sensor for the determination of $\mathrm{Ni}(\mathrm{II})$ in both solution and PAD format was described by Jun-jie et al. [51]. The reagent $\mathrm{Zircon}$ incorporated with $\mathrm{ZnSiO}_{3}$ nanospheres was employed as hybrid ionophore. A color change from red to blue further discolors in the presence of increasing $\mathrm{Ni}(\mathrm{II})$ concentrations. The selectivity of the assay can be improved adding $\mathrm{Na}_{2}$-ethylenediaminetetraacetic acid $\left(\mathrm{Na}_{2}\right.$-EDTA) as co-ionophore. The LOD of the sensor was $36 \mathrm{nM}$ Ni in solution and $83 \mathrm{nM}$ in the PAD. Scanning of PADs and image processing by ImageJ software were used.

Shrivas et al. [52] reported a smartphone-paper based sensor for detection of Fe(III) in water and blood. A solution of Ag modified with cetyltrimethylammonium bromide was used as recognition element. The change in color of AgNPs/cetyltrimethylammonium bromide (AgNPs/CTAB) which occurs in the presence of Fe(III) is measured using a smartphone and ImageJ software. The discoloration observed is explained on the basis of an electron transfer reaction. A LOD of $20 \mu \mathrm{g} / \mathrm{L}$ with a RSD of $3.2 \%$ was obtained.

Dong et al. [53] designed a colorimetric paper sensor which relies on belt-like ZnSe nanoframes consisting of numerous ZnSe nancrystals. The sensing mechanism is based on the cation-exchange characteristic of chalcogenides, allowing the detection of $\mathrm{Ag}(\mathrm{I}), \mathrm{Cu}(\mathrm{II})$, and $\mathrm{Hg}$ (II). $\mathrm{Cu}$ (II) could be detected at a level below 1 ppm whereas for $\mathrm{Hg}$ (II) and $\mathrm{Ag}$ (I) the detection limit was below 5 ppm.

So far, most paper-based assays were developed following the capture of light reflection (color intensity) using a scanner or camera and further processing of the image with image analysis software. In the transmission mode, a portable transmission densitometer is employed. With this measurement mode, an improvement in the accuracy and sensitivity for detection of high concentrations is achieved. This approach was applied to the determination of $\mathrm{Cu}(\mathrm{II}), \mathrm{Fe}(\mathrm{III})$, and $\mathrm{Ni}(\mathrm{II})$, but conventional chromogenic agents were employed [67].

A few papers have addressed the direct determination of anionic species using PADs along with nanomaterials as receptors.

The determination of chloride was carried out on the basis of the oxidative etching of AgNPs in the presence of $\mathrm{Cl}^{-}$and $\mathrm{H}_{2} \mathrm{O}_{2}$ which causes a white precipitate of $\mathrm{AgCl}$ [68]. A distance-based microPAD is employed where the length of the white band is proportional to the chloride concentration in the water samples. The LOD reached by naked eye is 2 ppm with a RSD less than $4.51 \%$.

\subsection{Fluorescent Nanoparticles Immobilized onto Cellulose Substrates}

Several fluorescent nanostructured materials have been implemented mostly in PADs for the detection of metal ions. Thus, inorganic quantum dots [69], carbon dots and graphene carbon dots [70], and metal nanoclusters [71] have shown a great potential for designing new sensors so their implementation as receptors for building new assays on cellulose platforms is very promising. Luminescent nanoparticles possess quantum yields much higher than those of conventional organic fluorophores as well as enhanced chemical and photoluminescent stability.

Applications have been mainly focused on $\mathrm{Hg}(\mathrm{II}), \mathrm{Cu}(\mathrm{II})$, and Se(IV). Table 2 shows main applications [72-92] where luminescent nanoreceptors are immobilized onto cellulose substrates for sensing trace elements. Direct deposition of the sample onto the PAD is considered here. Assays where the PAD is combined with an enrichment process will be addressed in Section 4. 
Table 2. Applications of the detection of metal ions by PADs and microPADs using luminescent nanomaterials as receptors.

\begin{tabular}{|c|c|c|c|c|c|c|}
\hline Target Analyte & Sample/Matrix & Nanostructured Receptor & Sensor Design & Signal Acquisition & Analytical Characteristics & Ref. \\
\hline $\mathrm{Se}(\mathrm{IV})$ & Hair, sediment, urine & CdTe QDs & PAD & $\begin{array}{l}\text { Fluorescence under } \\
\text { UV irradiation }\end{array}$ & $0.1 \mathrm{ppb}$ Se & [72] \\
\hline $\mathrm{Hg}(\mathrm{II}), \mathrm{Pb}(\mathrm{II}), \mathrm{Cu}(\mathrm{II})$ & River water & CDs & PAD (microarray) & Smartphone & $\begin{array}{c}5.8 \mathrm{nM}(\mathrm{Hg}) \\
0.12 \mu \mathrm{M}(\mathrm{Pb}) \\
0.076 \mu \mathrm{M}(\mathrm{Cu})\end{array}$ & [73] \\
\hline $\mathrm{Hg}(\mathrm{II})$ & Wastewater & $\begin{array}{c}\text { GQDs } \\
\text { (N, S-codoped) }\end{array}$ & PAD & $\begin{array}{l}\text { Digital camera } \\
\text { (UV irradiation) }\end{array}$ & $0.14 \mathrm{nM}$ & [74] \\
\hline $\mathrm{Ce}(\mathrm{III})$ & River water & Carbon dots & PAD & $\begin{array}{l}\text { Naked eye } \\
\text { (UV irradiation) }\end{array}$ & $\begin{array}{c}0.7 \mu \mathrm{M} \\
\text { (fluorimetry) }\end{array}$ & [75] \\
\hline $\mathrm{Fe}(\mathrm{III})$ & - & N-doped GQDs & PAD & $\begin{array}{l}\text { Naked eye } \\
\text { (UV irradiation) }\end{array}$ & $\begin{array}{c}2.37 \mu \mathrm{M} \\
\text { (fluorimetry) }\end{array}$ & [76] \\
\hline $\operatorname{Hg}(\mathrm{II})$ & Water, urine & $\begin{array}{c}\text { CdSe/ZnS QDs } \\
\text { (functionalized with HDTC) }\end{array}$ & PAD & $\begin{array}{l}\text { Naked eye } \\
\text { (UV irradiation) } \\
\text { Naked eye }\end{array}$ & $0.2 \mathrm{ppm} \mathrm{Hg}$ & [77] \\
\hline $\operatorname{Ag}(I), \operatorname{AgNPs}$ & River water & CdTe QDs & PAD & $\begin{array}{c}\text { (UV irradiation, } \\
\text { distance measurement) }\end{array}$ & $0.01 \mathrm{ppm}(\mathrm{Ag})$ & [78] \\
\hline $\mathrm{Se}(\mathrm{IV})$ & $\begin{array}{l}\text { Tap water, seawater } \\
\text { fish, rice, eggs }\end{array}$ & AuNCs & PAD & $\begin{array}{l}\text { Naked eye } \\
\text { (UV irradiation) } \\
\text { and fluorimetry }\end{array}$ & $4 \mathrm{ppb}(\mathrm{Se})$ & [79] \\
\hline $\mathrm{Al}(\mathrm{III})$ & 一 & C-dots-R6G & PAD & $\begin{array}{l}\text { Digital camera } \\
\text { (UV irradiation) } \\
\text { and fluorimetry }\end{array}$ & $3.89 \times 10^{-5} \mathrm{M}(\mathrm{PAD})$ & [80] \\
\hline Tri-butyl-Sn & Seawater & $\begin{array}{l}\text { GQDs conjugated with } \\
\text { MIN }\end{array}$ & PAD & Fluorimetry & $0.23 \mathrm{ppt}$ & [81] \\
\hline $\mathrm{Hg}(\mathrm{II}), \mathrm{Cu}(\mathrm{II})$ & $\begin{array}{l}\text { Tap and river } \\
\text { water }\end{array}$ & CS-CDs & $\begin{array}{l}\text { Sponge } \\
\text { cellulose }\end{array}$ & $\begin{array}{l}\text { Mobile camera } \\
\text { (UV irradiation) }\end{array}$ & $\begin{array}{c}26 \mathrm{nM}(\mathrm{Al}) ; \\
0.11 \text { and } 3 \mu \mathrm{M}(\mathrm{Cu}), \\
\text { by fluorimetry and } \mathrm{PAD}, \\
\text { resp. }\end{array}$ & [82] \\
\hline $\mathrm{Cu}(\mathrm{II})$ & $\begin{array}{l}\text { Tap water, } \\
\text { Lake water }\end{array}$ & Hybrid CdTe-CDs & PAD & $\begin{array}{l}\text { Digital camera } \\
\text { (UV irradiation) }\end{array}$ & $\begin{array}{c}0.36 \mathrm{nM} \\
\text { (fluorimetry) }\end{array}$ & [83] \\
\hline $\mathrm{Cu}(\mathrm{II})$ & $\begin{array}{l}\text { Urine, tap water, } \\
\text { Sorghum extract }\end{array}$ & BSA-AuNCs & PAD & $\begin{array}{l}\text { Naked eye } \\
\text { (UV irradiation) }\end{array}$ & $\begin{array}{c}5 \mathrm{nM} \\
\text { (fluorimetry) }\end{array}$ & [84] \\
\hline $\mathrm{Cu}(\mathrm{II}), \mathrm{Hg}(\mathrm{II})$ & Tap water & N-doped CDs & $\mu \mathrm{PAD}$ & $\begin{array}{l}\text { Digital camera } \\
\text { (UV irradiation) }\end{array}$ & $\begin{array}{c}0.1 \mu \mathrm{M}(\mu \mathrm{PAD}) ; \\
6.2 \mathrm{nM}(\mathrm{Hg}), 2.3 \mathrm{nM} \\
(\mathrm{Cu}) \text { by fluorimetry }\end{array}$ & [85] \\
\hline
\end{tabular}


Table 2. Cont.

\begin{tabular}{|c|c|c|c|c|c|c|}
\hline Target Analyte & Sample/Matrix & Nanostructured Receptor & Sensor Design & Signal Acquisition & Analytical Characteristics & Ref. \\
\hline $\mathrm{Cu}(\mathrm{II}), \mathrm{Hg}(\mathrm{II})$ & Tap and lake water & CQDs & PAD & Naked eye & $5(\mathrm{Cu}), 3(\mathrm{Hg})(\mu \mathrm{M})$ & [86] \\
\hline $\mathrm{Zn}(\mathrm{II})$ & Water, blood, cells & AuNCS & PAD & $\begin{array}{l}\text { Naked eye } \\
\text { and fluorimetry }\end{array}$ & $\begin{array}{c}3 \mathrm{ppb} \text { (fluorimetry) } \\
20 \mathrm{ppb} \text { (naked eye } \\
\text { under UV irradiation) }\end{array}$ & [87] \\
\hline $\mathrm{Co}(\mathrm{II})$ & - & ZnS QDs & PAD & Mobile camera & 10 ppm & [88] \\
\hline $\mathrm{Cu}(\mathrm{II})$ & - & $\mathrm{ZnO}$ NPs & PAD & Mobile camera & $10 \mu \mathrm{M}$ & [89] \\
\hline $\mathrm{Hg}(\mathrm{II})$ & $\begin{array}{l}\text { Tap water } \\
\text { Lake water }\end{array}$ & CDs & PAD & $\begin{array}{l}\text { Naked eye } \\
\text { (UV irradiation) }\end{array}$ & $0.14 \mu \mathrm{M}$ & [90] \\
\hline $\mathrm{Pb}(\mathrm{II})$ & - & CDs & PAD & $\begin{array}{c}\text { Fluorimetry and } \\
\text { naked eye }\end{array}$ & $\begin{array}{c}0.055 \mu \mathrm{M} \\
\text { (fluorimetry) }\end{array}$ & [91] \\
\hline $\mathrm{Pb}(\mathrm{II})$ & Waters & CDs & PAD & $\begin{array}{c}\text { Fluorimetry and } \\
\text { smartphone camera }\end{array}$ & $\begin{array}{c}2.89 \mathrm{nM} \text { (fluorimetry) } \\
45.9 \mathrm{nM} \text { (PAD) }\end{array}$ & [92] \\
\hline
\end{tabular}


It is necessary to highlight that in a significant number of papers published, LODs are referred to the application of the probe in solution using fluorimetry.

\subsubsection{Quantum Dots}

Quantum dots (QDs) are fluorescent nanocrystals made from semiconductor materials, usually of spherical shape and a size less than $10 \mathrm{~nm}$ in diameter. QDs display excellent photoluminescent properties [69]. Typical QDs composition includes elements of groups II-VI (e.g., CdSe), III-V (e.g., InAs), and IV-VI (e.g., PbS), and core-shell systems (e.g., CdSe/ZnS).

A paper-based sensor has been reported for visual detection of $\mathrm{Hg}(\mathrm{II})$. For this, 2hydroxyethyldithiocarbamate (HDTC)-QDs were immobilized onto cellulose acetate [77]. A color change due to the high affinity of HDTC on the surface of CdSe/ZnS QDs toward $\mathrm{Hg}$ (II) occurs. An orange fluorescence was displayed under $365 \mathrm{~nm}$ UV lamp which changes to red in the presence of $\mathrm{Hg}$. The LOD of $\mathrm{Hg}(\mathrm{II})$ was $0.2 \mathrm{ppm}$ with this approach.

Inkjet-printed CdTe QDs onto a paper strip were used for speciation of $\mathrm{Ag}(\mathrm{I})$ and AgNPs by distance-based readout method [78]. The capillary movement of $\mathrm{Ag}^{+}$up to the strip causes the quenching of the fluorescence from CdTe QDs due to a cation exchange reaction between $\mathrm{Ag}^{+}$and $\mathrm{CdTe}$ QDs. The height of the quenched fluorescent band is proportional to the Ag concentration in the solution. However, no quenching occurred in the presence of AgNPs, thus enabling speciation of both species. For the detection of total $\mathrm{Ag}$, a digestion with conc. $\mathrm{HNO}_{3}$ was carried out so as to convert AgNPs into $\mathrm{Ag}^{+}$. A LOD of 0.01 ppm Ag was obtained. Thus, a disposable and instrument-free method was accomplished for on-site identification and speciation of $\mathrm{Ag}^{+}$and $\mathrm{AgNPs}$.

The formation of $\mathrm{CoS}_{2}$ when a paper-based sensors uses $\mathrm{ZnS}$ as a receptor is used for detection of $\mathrm{Co}$ (II) [88]. The strong absorption in the visibility of $\mathrm{CoS}_{2}$ formed a brown color which allows its measurement by a mobile camera and further color processing using image software.

Liu et al. [89] reported a PAD with fluorescent ZnO NPs as probe for the detection of $\mathrm{Cu}(\mathrm{II})$. Quenching of the fluorescence occurs in the presence of the analyte. Fluorescence images were taken by a mobile phone camera following irradiation with an UV lamp. A detection range of $10-1000 \mu \mathrm{M}$ is obtained.

\subsubsection{Carbon Quantum Dots and Graphene Quantum Dots}

Carbon quantum dots (CQDs), also known as carbon dots (CDs), are fluorescent spherical NPs made of carbon with a diameter less than $10 \mu \mathrm{m}$. Unlike inorganic QDs, carbon-based fluorescent nanomaterials can be easily synthesized from nontoxic precursors and under green synthetic methods. In addition, they are highly soluble in aqueous media. Although their quantum yield is lower than that of inorganic QDs, it can be improved by suitable doping. Graphene quantum dots (GQDs) are fluorescent $\pi$-conjugated single sheets (i.e., disk of graphene in the size range of 2-20 nm). Both possess unique optical properties including strong luminescence, and therefore, their potential for the design of new sensors has been widely recognized [70].

Xiao et al. [73] reported recently a paper-based microarray for multiplexed detection of $\mathrm{Hg}(\mathrm{II}), \mathrm{Pb}(\mathrm{II})$, and $\mathrm{Cu}(\mathrm{II})$ based on colorimetric measurements using a smartphonebased sensing system. With this approach, reported results can be generated and shared via wireless network. For this purpose, three kinds of CDs with different fluorescent characteristics were immobilized onto the cellulose substrate to develop a microarray chip. The presence of metal ions gave rise to a decrease in fluorescence of CDs. LODs of $5.8 \mathrm{nM}$ $(\mathrm{Hg}), 0.12 \mu \mathrm{M}(\mathrm{Pb})$, and $0.076 \mu \mathrm{M}(\mathrm{Cu})$ were obtained.

Ngoc Anh et al. [74] developed a paper strip coated with N,S-codoped GQDs for sensing $\mathrm{Hg}(\mathrm{II})$ in wastewater. The quantum yield of $\mathrm{N}, \mathrm{S}-\mathrm{GQD}$ reached $41.9 \%$. $\mathrm{Hg}$ (II) quenched the fluorescence of N,S-GQDs, and an LOD of $0.14 \mathrm{nM}$ (in the assay carried out in solution) was achieved. A rapid screening of $\mathrm{Hg}$ in wastewater can be performed after filtration and removal of impurities by solid phase extraction followed by UV irradiation 
of paper strips. A digital camera was used for measuring the color. $\mathrm{Hg}$ (II) can easily interact with $\mathrm{S}$ atoms, as a result of soft acid and soft base coordination, which results in fluorescence quenching.

$\mathrm{Li}$ et al. [75] reported a paper sensor based on fluorescent CDs for the detection of $\mathrm{Ce}(\mathrm{III})$, with a LOD of $0.7 \mu \mathrm{M}$. Recognition event caused a 'turned off' response. The cellulose acetate paper was immersed in a CQDs solution and dried in order to accomplish the sensor. The emission of the test paper was observed by the naked eye under UV irradiation at $365 \mathrm{~nm}$.

Applications of paper-based sensors for elemental speciation is very scarce. Sari et al. [81] described a novel photoluminescent nanocomposite, namely, molecularly imprinted nanoparticles coupled with graphene quantum dots (GMIN) were added onto nitrocellulose membranes ( $6 \mathrm{~mm}$ diameter). The sensor allowed the determination of tributyltin (TBT) with high selectivity and sensitivity in seawater, reaching a LOD of 0.23 ppt. The method allows to circumvent drawbacks inherent to conventional central instrumentation typically employed for TBT detection such as gas chromatography-mass spectrometry (GC-MS) or gas spectrometry-inductively coupled plasma-mass spectrometry (GC-ICP-MS), which are expensive, time-consuming, requiring sophisticated equipment and high technical skills.

A novel dual-emission ratiometric fluorescence sensor was developed by Wang et al. [83] for the detection of $\mathrm{Cu}(\mathrm{II})$. For this, a hybrid system integrated by carboxylmodified red fluorescent CdTe QDs and amino-functionalized blue fluorescent carbon nanodots (CDs) was designed. Cu causes the quenching of the red fluorescence of $\mathrm{CdTe}$ QDs whereas the blue fluorescence of CDs is used as internal standard. In this way, a change in fluorescence color from pink to blue occurs, which can be observed by the naked eye under a UV lamp. A LOD of $0.36 \mathrm{nM} \mathrm{Cu}$ is achieved, which is much lower than the maximum contamination level given by the United States Environmental Protection Agency (US EPA) in drinking water $(20 \mu \mathrm{M})$. The sensor was applied to lake water and tap water. The ratiometric probe can be adapted to a paper-based sensor. The probe was printed using the probe solution as ink, thus facilitating advantages of portability and easy operation and opening the door to $\mathrm{Cu}$ detection in biological, chemical, and environmental fields without complex instrumentation.

Nitrogen-doped carbon dots were prepared using a one pot method from urea and EDTA for the parallel sensing of $\mathrm{Hg}$ (II) and $\mathrm{Cu}$ (II) using assays carried out in both solution and cellulose substrates following an on-off-on strategy [85]. LODs of 6.2 and $2.3 \mathrm{nM}$ for $\mathrm{Hg}$ and $\mathrm{Cu}$, respectively, for assays performed in solution were reported. LODs of 0.1 and $50 \mu \mathrm{M}$ for the assays performed on filter paper and a microfluidic device were observed. Fluorescence was quenched by both $\mathrm{Cu}$ and $\mathrm{Hg}$, and the quenched fluorescence is recovered $(\mathrm{on})$ in the presence of ascorbic acid $(\mathrm{Hg})$ and citrate $(\mathrm{Cu})$, which allows to discriminate $\mathrm{Hg}(\mathrm{II})$ and $\mathrm{Cu}(\mathrm{II})$ ions.

Wang et al. [90] described a paper-based sensor for visual detection of $\mathrm{Hg}(\mathrm{II})$ using dual-colored carbon dot ratiometric fluorescent test. $\mathrm{Hg}$ (II) caused the quenching of the blue fluorescence. The red fluorescence served the purpose of internal standard. Quenching occurs as a result of aggregation induced by $\mathrm{Hg}$ (II) whereas the red fluorescence remains unaffected. Thus, a ratiometric sensing approach provided a LOD of $0.14 \mathrm{nM} \mathrm{Hg}$, which is much lower than the maximum contamination level recommended by US EPA for $\mathrm{Hg}$ $(10 \mathrm{nM})$ in drinking water.

A ratiometric fluorescent nanoprobe based on label-free carbon dots was applied to the selective determination of $\mathrm{Pb}(\mathrm{II})$ and pyrophosphate (PPi) [91]. Emission bands of CDs at 477 and $651 \mathrm{~nm}$ were used for sequential detection of $\mathrm{Pb}$ (II) and PPi, with LODs of 0.055 and $0.089 \mu \mathrm{M}$, respectively. The fluorescence at $651 \mathrm{~nm}$ was quenched by $\mathrm{Pb}(\mathrm{II})$, whereas the fluorescence at $477 \mathrm{~nm}$ remained constant (change from pink to cyan). When PPi was added, a change from cyan to pink occurred.

Dual-emission carbon dots (blue and red CDs) were applied by Wang et al. [92] for speciation analysis of $\mathrm{Pb}(\mathrm{II})$. The fluorescent probe was inkjet-printed on filter paper and 
the color was measured using a smartphone upon irradiation of paper substrates with a UV lamp. The blue fluorescence (maximum fluorescence emission peak at $452 \mathrm{~nm}$ ) was quenched by $\mathrm{Pb}$ (II) whereas the red fluorescence (maximum fluorescence emission peak at $620 \mathrm{~nm}$ ) remained unchanged. A LOD of 2.89 and $45.9 \mathrm{nM}$ was obtained when using a luminescence spectrometer and a smartphone, respectively. The sensor allows detection of $\mathrm{Pb}(\mathrm{II})$ in drinking water at a concentration below the maximum contamination level established by US EPA.

\subsubsection{Metal Nanoclusters}

Metal nanoclusters (NCs) are made of $\mathrm{Au}, \mathrm{Ag}, \mathrm{Cu}$, etc., and possess a size smaller than that of metal nanoparticles (NPs). Unlike metal NPs, metal NCs do not display the surface plasmon resonance effect, but they are strongly luminescent [71].

Yuan et al. [77] described an on-site visual method for $\mathrm{Hg}$ detection based on CdSe/ZnS QDs functionalized with HDTC. The quenching effect of $\mathrm{Hg}$ on the QDs fluorescence due to the formation of a chelate complex on the surface of QDs provided a LOD of $1 \mathrm{ppb}$. When the assay was performed on a cellulose substrate upon immobilization of HDTC-QDs, a visual color change from orange to red under a UV lamp was observed depending on the Hg concentration, a LOD of 200 ppb being achieved.

Xiong et al. [79] described a paper-based assay using fluorescent AuNCs as receptors and hydride generation to convert $\mathrm{Se}(\mathrm{IV})$ into $\mathrm{SeH}_{2}$ (Figure 5A). AuNCs serve two purposes, i.e., they catalyze the oxidation of $\mathrm{SeH}_{2}$ to yield $\mathrm{Se}(0)$ that is deposited onto the surface of AuNCs, thus causing fluorescence quenching (recognition event). The separation of $\mathrm{Se}(\mathrm{IV})$ as $\mathrm{SeH}_{2}$ and its interaction with AuNCs supported paper is carried out inside a vial. An outstanding advantage of this assay is its high tolerance to matrix interferences, overall saline solutions, since a separation is carried out prior to sensing, e.g., $5 \% \mathrm{~m} / \mathrm{V}$ salt concentration did not cause any interference effect. An LOD of 4 ppb Se(IV) was achieved with a repeatability around $2.8 \%$. Applications to biological samples and food samples, as well as several waters, proved a suitable performance.

A FRET (Foster resonance energy transfer)-based ratiometric rhodamine immobilized onto CDs was applied for selective $\mathrm{Al}$ (III) detection using a paper-based sensor strip [80]. The sensor showed two well-resolved emission peaks, one due to the blue fluorescence of CDs and the other due to the yellow fluorescence of rhodamine moiety. A digital camera was employed to study the changes in emission colors (blue to greenish-yellow) on the paper-based strip. LODs of the assay in solution and on the paper sensor were similar, $3.89 \times 10^{-5} \mathrm{M}$, although the linear range was broader with the paper sensor.

Immobilization of BSA-AuNCs on wax-printed paper was applied to $\mathrm{Cu}$ (II) detection [84]. BSA-Au NCs were corroded upon oxidation by $\mathrm{H}_{2} \mathrm{O}_{2}$ in the presence of $\mathrm{NH}_{3} / \mathrm{NH}_{4} \mathrm{Cl}$ buffer and $\mathrm{SCN}^{-}$, which results in fluorescence loss of the probe. When $\mathrm{Cu}(\mathrm{II})$ is added, the red fluorescence is kept since the complex $\mathrm{Cu}\left(\mathrm{NH}_{3}\right)_{6}{ }^{2+}$ can decompose $\mathrm{H}_{2} \mathrm{O}_{2}$. The lost in fluorescence can be related to the $\mathrm{Cu}(\mathrm{II})$ concentration in the sample. The potential of this method for field analysis was accomplished by immobilization onto paper. Moreover, typical interferences such as $\mathrm{Hg}$ (II) when using AuNCs probes does not occur in this case. Urine, tap water, and sorghum extract were successfully analyzed. 


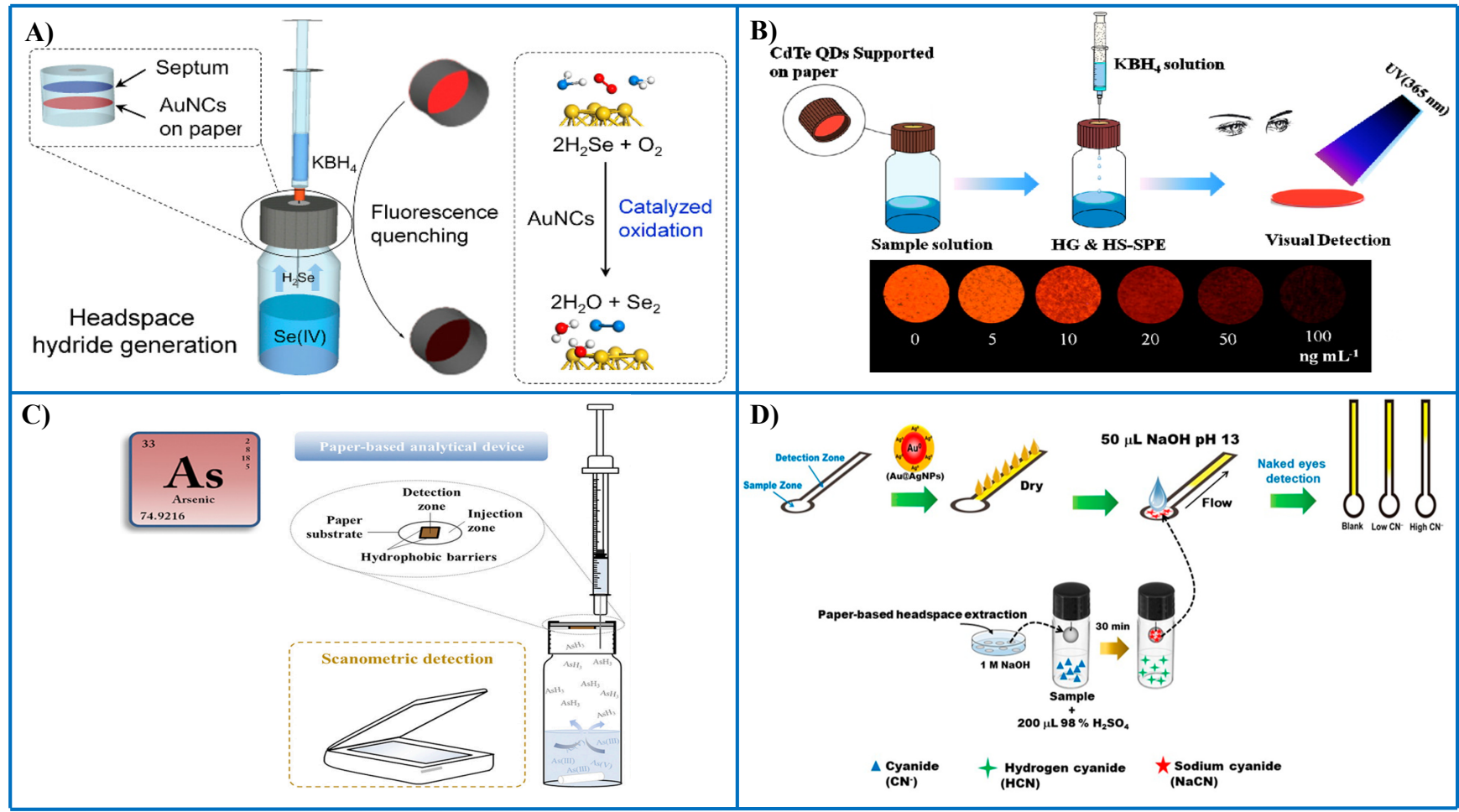

Figure 5. Representative examples of the combination of PADs and thin-film microextraction for the detection of different metal species and anions. (A) PAD with AuNCs as fluorescent probes and integrated with thin-film microextraction for sensing Se(IV) following hydride generation [79]; (B) PAD with CdTd QDs as nanoreceptors for the determination of Se(IV) following hydride generation [72]; (C) PAD integrated with thin-film microextraction for the determination of total As and speciation of As(III) and As(V) [93]; (D) distance-based microPAD for the determination of cyanide using Au/Ag NPs as probes; a prior preconcentration in a drop was carried out to improve sensitivity [94]. (D). Figure 5A-C is reproduced with permission of the American Chemical Society [72,79] and Elsevier [93].

A paper-based sensor along with a smartphone including a home-made image processing algorithm was proposed by Incel et al. [95] for the determination of cyanide. For this, the fluorescent orgametallic dye, europium tetrakis dibenzoylmethide triethyammonium (EuD4TEA) was deposited on the paper surface. Addition of AuNPs caused the quenching of EuD4TEA fluorescence. Upon addition of cyanide solution, a fluorescence recovery and enhancement was observed. Color was processed and the red component was seen to have a linear correlation with cyanide concentration. A LOD as low as $10^{-12} \mathrm{M}$ was achieved. Clear water samples are needed due to interference of colored and crude samples.

Itthiporn et al. [56] described a PAD with enhanced sensitivity for iodate detection by integrating a membraneless gas-separation and a PAD with BSA-AuNCs as sensing probe (Figure 4C). For this, prior reduction of iodate to iodine was performed. The etching of the Au core gives rise to the fluorescence quenching of the probe. Both fluorimetry using a sample holder for the PAD and color measurements under UV illumination following image capture with a smartphone camera are performed. LODs of $0.005 \mathrm{mM}$ (fluorimetry) and $0.01 \mathrm{mM}$ (image capture) are obtained. RSD values were less than $3 \%$. Determination of iodate in fish sauces and iodized salts was successfully carried out.

\section{Strategies for Enhancing Sensitivity of Paper-Based Analytical Devices}

Many PADs and microPADs developed lack the sufficient detection capability for direct detection of metal ions in environmental samples. This is especially a major problem for metals such as $\mathrm{Hg}, \mathrm{Cd}$, and to a lesser extent $\mathrm{Pb}$, with maximum contaminant levels in the range of $1-15 \mathrm{ppb}$ (Table 3). It is necessary to highlight that in many applications reported in Tables 1 and 2, very good LODs are obtained when the assay is carried out in liquid phase with a lab instrument (photometer or fluorimeter), but much worse LODs are 
observed when the assay is accomplished with image capture. It is generally observed that improved LODs are achieved when applying PADs designs along with nanostructured receptors. In recent years, several strategies have been tried so as to cope with the low concentrations of most metals ions in waters and other environmental samples. In the following section, main strategies attempted for improving sensitivity and LOD along with PADs and microPADs are discussed.

Table 3. Concentration values of metal ions and anionic species regulated by EPA, WHO, and European Directive in drinking waters.

\begin{tabular}{|c|c|c|c|}
\hline Chemical Species & EPA $^{a}$ & WHO $^{b}$ & European Directive $^{c}$ \\
\hline $\mathrm{Al}$ & - & - & $200 \mathrm{ppb}$ \\
\hline As & $10 \mathrm{ppb}$ & $10 \mathrm{ppb}$ & $10 \mathrm{ppb}$ \\
\hline $\mathrm{Sb}$ & $6 \mathrm{ppb}$ & $20 \mathrm{ppb}$ & $5 \mathrm{ppb}$ \\
\hline $\mathrm{Ba}$ & $2 \mathrm{ppm}$ & $1.3 \mathrm{ppm}$ & \\
\hline $\mathrm{Be}$ & $4 \mathrm{ppb}$ & & \\
\hline $\mathrm{Cd}$ & $5 \mathrm{ppb}$ & $3 \mathrm{ppb}$ & $5 \mathrm{ppb}$ \\
\hline $\mathrm{Cr}(\mathrm{T})$ & $100 \mathrm{ppb}$ & $50 \mathrm{ppb}$ & $50 \mathrm{ppb}$ \\
\hline $\mathrm{Cu}$ & $\mathrm{TT}^{*}$ action level $=1.3 \mathrm{ppm}$ & $2 \mathrm{ppm}$ & $2 \mathrm{ppm}$ \\
\hline $\mathrm{Pb}$ & $\mathrm{TT}^{*}$ action level $=15 \mathrm{ppb}$ & 10 & $10 \mathrm{ppb}$ \\
\hline $\mathrm{Hg}$ & $2 \mathrm{ppb}$ & $6 \mathrm{ppb}$ & $1 \mathrm{ppb}$ \\
\hline Se & $50 \mathrm{ppb}$ & $40 \mathrm{ppb}$ & $10 \mathrm{ppb}$ \\
\hline $\mathrm{Tl}$ & $2 \mathrm{ppb}$ & & \\
\hline $\mathrm{Ni}$ & - & $70 \mathrm{ppb}$ & $20 \mathrm{ppb}$ \\
\hline $\mathrm{B}$ & - & $2.4 \mathrm{ppm}$ & $1 \mathrm{ppm}$ \\
\hline $\mathrm{U}$ & - & $30 \mathrm{ppb}$ & \\
\hline $\mathrm{Fe}$ & - & - & $200 \mathrm{ppb}$ \\
\hline $\mathrm{Mn}$ & - & - & $50 \mathrm{ppb}$ \\
\hline Cyanide & $200 \mathrm{ppb}$ & & $50 \mathrm{ppb}$ \\
\hline Fluoride & $4 \mathrm{ppm}$ & $1.5 \mathrm{ppm}$ & $1.5 \mathrm{ppm}$ \\
\hline Nitrate & 10 ppm & 50 ppm & 50 ppm \\
\hline Nitrite & 1 ppm & 3 ppm & $0.5 \mathrm{ppm}$ \\
\hline Bromate & $10 \mathrm{ppb}$ & $10 \mathrm{ppb}$ & $10 \mathrm{ppb}$ \\
\hline Chlorite & $1 \mathrm{ppm}$ & $0.7 \mathrm{ppm}$ & \\
\hline Chlorate & - & $0.7 \mathrm{ppm}$ & \\
\hline Chloride & & & $250 \mathrm{ppm}$ \\
\hline Sulphate & - & - & $250 \mathrm{ppm}$ \\
\hline
\end{tabular}

a Maximum contaminant level ${ }^{\mathrm{b}}$ Guideline value ${ }^{\mathrm{c}}$ Parametric value ${ }^{*}$ TT: treatment technique.

\subsection{Optimization of PAD and MicroPAD Design}

Nguyen et al. [96] have addressed the main shortcomings inherent to the use of microPADs. Liquid suction upon capillary pressure is a fundamental mechanism which explains the flow in two phases (porous network). The main problem is the sample retention and evaporation occurring within the cellulose network, which ultimately limits the transport of analyte to the detection zone and hampers the LOD. Increased performance of microPADs was achieved following the study of variables such travel distances, wax barriers, shape of detection, and sampling zones, etc. For instance, sensitivity was increased by $28 \%$ for the detection of $\mathrm{Ni}(\mathrm{II})$ when those parameters were optimized.

In relation with PADs, Tan et al. [39] reported a paper-based sensor for determination of $\mathrm{Cr}(\mathrm{VI})$ in drinking water. Two shortcomings of PADs are addressed in this paper, i.e., the 'coffee ring' effect, which impairs the uniform distribution of the analyte on the cellulose substrate and the high absorbent capacity of common filter paper (Whatman) which facilitates penetration of the sample through the surface, thereby decreasing color intensity. For this, a sensor based on a chemical-responsive adhesive tape was used for improving uniformity of sample distribution on paper. Moreover, the filter paper was subjected to a preliminary superhydrophobic treatment so as to preconcentrate $\mathrm{Cr}(\mathrm{VI})$ to a small spot following evaporation of the sample solution. The concentrated spot on the paper surface shows higher reflective intensity as compared to a conventional paper-based 
sensor. 1,5-diphenylcarbazide was used as a receptor of $\mathrm{Cr}(\mathrm{VI})$ upon complexation through the -SH groups. With this approach it is possible to detect $\mathrm{Cr}(\mathrm{VI})$ concentration levels as low as $0.05 \mathrm{ppm}$, thus improving by a factor of 10 the sensitivity of conventional PADs.

However, further improvements of microPADs and PADs design seem to have reached a limit, so new strategies for spreading PADs to the analysis of trace elements in environmental samples are needed. In the following sections, main achievements addressed to improving sensitivity of PADs are discussed.

\subsection{Preconcentration Strategies in Paper-Based Analytical Devices}

\subsubsection{Repetitive Deposition of Sample onto the Cellulose Substrate}

Most attempts performed with PADs have involved repetitive deposition of sample aliquots for enrichment. Several cycles of deposition/drying are carried out to achieve the suitable sensitivity. The procedure is easy to accomplish but it is labor-intensive and it requires long operation times.

Thus, several metal ions such as $\mathrm{Ag}(\mathrm{I}), \mathrm{Cd}(\mathrm{II}) \mathrm{Cu}(\mathrm{II}), \mathrm{Hg}(\mathrm{II})$, etc., have been determined in environmental samples after enrichment, involving prior reaction with pyridilazo receptors [97]. This strategy enables along with the use of chemometric tools the detection of eight elements at microM level. Other PAD using CURNPs as receptors [48] has been used for detection of $\mathrm{Hg}$ (II) after 50 accumulation cycles onto the PAD aimed at reaching $\mathrm{Hg}$ levels regulated by EPA. Likewise, detection of $\mathrm{Hg}$ (II) has been reported using a smartphone and AgNPs as receptor following repetitive accumulation in order to achieve a LOD of 3 ppb Hg [98].

Sharifi et al. [38] have developed 3D origami micro-PADs where a polyvinyl-chloride $(\mathrm{PVC})$ membrane was used to immobilize the chromogenic reagents on the paper surface. This prevents the heterogeneous deposition of the reagents and leaching out the dye due to movement of colored products from the center of the spot to edge of the detection zone, and results in improved sensitivity and LODs. In addition, with the implementation of a waste layer, increased sample volumes can be used. With chrome azurol $\mathrm{S}$ and pyrocatechol violet, LODs of 1.7 and $1.9 \mathrm{ppm} \mathrm{Cu}$ were achieved along with an extended dynamic range of calibration.

\subsubsection{Preconcentration by Solid-Phase Extraction}

Cellulosic materials have attracted much interest in recent years, as sorbents for preconcentration and isolation of pollutants in environmental samples. While the presence of hydroxyl groups onto this biopolymer makes it very hydrophilic, these groups also allow many modifications of the cellulose surface. As a result, cellulose-based materials show a great potential as sorbent for several modern preconcentration techniques such as solid-phase extraction (SPE), solid-phase microextraction (SPME), thin-film microextraction (TFME), magnetic-SPE, dispersive-SPME, etc. [99].

Quinn et al. [37] reported a distance-based microPAD as a fast screening tool for $\mathrm{Cu}$ monitoring in water systems with a previous preconcentration by solid-phase extraction. A LOD of $20 \mathrm{ppb} C \mathrm{Cu}$ was obtained and methodology was validated against ICP-MS.

Preconcentration of $\mathrm{Pb}(\mathrm{II})$ in water samples has been performed using a cellulose filter containing a sorbent, i.e., $\mathrm{Zr}$ silicate [41]. A continuous flow system allows to load the water sample onto the filter in order to achieve a suitable enrichment. Finally the filter is placed in a PAD where $\mathrm{Pb}$ (II) comes in contact with the receptor, i.e., a sodium rhodizonate solution, thus allowing a LOD of $10 \mathrm{ppb} \mathrm{Pb}$. In addition, this strategy allows water preservation methods such as $\mathrm{pH}$ control, refrigeration, chemical addition, etc., as well as sample storing prior to analysis. The total analysis time including preconcentration and detection was less than $15 \mathrm{~min}$ for a $25 \mathrm{~mL}$ water sample.

De la Calle et al. [100] described a filtration device on cellulose paper modified with different metal nanoparticles (i.e., AgNPs, PdNPs, AuNPs) for the selective preconcentration of $\mathrm{Hg}(\mathrm{II})$. However, in this work, detection on the cellulose substrate was not attempted 
and $\mathrm{Hg}$ was directly measured in vapor phase after complete combustion of the substrate. A preconcentration factor about 3500 and a LOD of 0.2 ppt $\mathrm{Hg}$ in waters were achieved.

Zhang et al. [101] reported the determination of Cd(II) in rice after SPE and final detection using a PAD with a fluorogenic reagent, i.e., 4,4-difluoro-4-bora-3a,4a-diazasindacene (BODIPY). Fluorescence images of PADs illuminated with UV source light were taken with a digital camera and further digitized with Adobe Photoshop. A LOD of $0.5 \mu \mathrm{M}$ was obtained, analytical results being comparable to those obtained by inductively coupled plasma-mass spectrometry (ICP-MS).

\subsubsection{Preconcentration by Thin-Film Microextraction}

CdTe QDs were immobilized on a paper for detection of Se(IV) following hydride generation in a headspace (HS) microextraction system [72] (Figure 5B). Volatile $\mathrm{SeH}_{2}$ generated in the vial was extracted in the paper containing CdTe QDs acting as both receptors and preconcentration platforms. Visual detection of Se was accomplished after irradiation at $365 \mathrm{~nm}$ in an UV test box. Photoluminescent detection was also performed taking advantage of fluorescent properties of CdTe QDs using a solid sample holder in a fluorescence spectrometer. Since apart from preconcentration a liquid-gas separation occurs, application to complex matrices such as urine can be successfully performed. A LOD of $0.1 \mathrm{ppb} \mathrm{Se}(\mathrm{IV})$ with a RSD of $2.4 \%$ were reported.

Huang et al. [87] reported the combination of headspace (HS)-TFME and a PAD impregnated with AuNCs for the detection of $\mathrm{Zn}$ (II) in biological samples after generation of $\mathrm{ZnH}_{2}$ volatile. A LOD of 3 ppb $\mathrm{Zn}$ was achieved with a RSD better than $2 \%$. As pointed out above, a paper for the detection of Se(IV) has also been published following hydride generation and TFME onto a PAD impregnated with AuNCs [79].

Bagheri and Saraji [102] have combined headspace single-drop microextraction (HSSDME) following hydride generation and a paper-based sensor for detection of Se(IV). AuNPs were confined in the drop as receptors for Se(IV) sensing. Thus, analyte separation and preconcentration occurs in the drop containing AuNPs, and additionally, AuNPs serve the purpose of colorimetric probe when spotted onto cellulose paper. The aggregation of AuNPs in the presence of Se(IV) accounts for the redshift of the surface plasmon resonance, color changing from red to blue. This approach allows Se determination in high complexity matrices such as seawater with a quantification limit of $12 \mathrm{ppb}$.

Pena-Pereira et al. [93] described a paper-based sensor integrated in a microextraction device for As speciation in waters using silver nitrate as receptor (Figure 5C). Both As(III) and $\mathrm{As}(\mathrm{V})$ can be determined after conversion of these species in volatile arsine using sodium borohydride as reducing agent. Speciation can be accomplished on the basis of arsine generation at different $\mathrm{pH}$ conditions. The reaction between the receptor and the analyte gives rise to the formation of a colored product onto the PAD formed by nanoand microparticles of Ag. The sensor allows also as a screening method for total inorganic As monitoring in waters. An LOD as low as $1.1 \mathrm{ppb}$ As is obtained which is below the maximum contamination level set by US EPA in drinking water. Hydride generation in strong acid media allows arsine generation from As(III) and As(V), but if a weak acid (e.g., citric acid) is employed, only As(III) is reactive toward sodium borohydride. More importantly, this approach brings about several benefits in the development of novel PADs, i.e., no direct contact between the sample and the nanoreceptor occurs, so stability of the sensing surface is not a problem with complex samples such as seawater, wastewaters or complex biological samples; there is a preconcentration on the PAD, thus improving detection capability; it allows speciation analysis by implementing selective reactions in the sample vial.

A similar approach was employed by the authors [103] for the determination of iodide in water samples. Fluorescent CuNCs were employed in drop format under headspace single-drop microextraction configuration and using a PAD. The headspace sampling of iodine generated in situ allows an increase in selectivity and sensitivity for iodide sensing. An enrichment factor of ca. 1100 times was achieved, yielding a LOD of 1 ppb iodide with 
the drop sensor. Although less sensitive, the PAD can provide on-site sensing using a tablet camera.

Cyanide was determined in several types of waters (drinking water, seawater, tap water, and wastewater) by means of distance-based PAD using Au/Ag NPs as probes [94] (Figure 5D). The yellow band length caused by the probe decreased with increasing cyanide concentration. In order to increase the sensitivity of the assay, a headspace-single drop microextraction approach was implemented. The 30 -fold enrichment thus obtained enabled a LOD of $10 \mathrm{ppb}$ cyanide by the naked eye. In other approach, cyanide was determined in water and wastewater by combining a PAD impregnated with pyridine-barbituric acid and headspace extraction [104].

Sulphite was determined in food samples by combining a headspace-thin film microextraction with a PAD impregnated with Fe(III) + 1,10-phenanthroline [57] (Figure 4D). Sulfite was converted into $\mathrm{SO}_{2}$ in the vial after acidification, which caused the reduction of the $\mathrm{Fe}(\mathrm{III})$ to $\mathrm{Fe}(\mathrm{II})$, and in turn, the development of a red color in the PAD due to the complex formed between $\mathrm{Fe}(\mathrm{II})$ and the chromogenic reagent. A smartphone camera was employed for capturing the color image, providing a LOD of $0.04 \mathrm{ppb}$.

A headspace sampling device combined with a PAD as sensing platform for $\mathrm{SO}_{2}$ determination in wine has been described by Li et al. [105]. For this, 4-mercaptopyridine (Mpy)-modified $\mathrm{Au}$ nanorods (AuNRs)-reduced graphene oxide hybrids, anhydrous methanol, and starch-iodine complex were employed as probes. Both colorimetric and surface-enhanced Raman scattering (SERS) were applied as dual detection modes. Following the Karl Fischer reaction, the deep-blue color due to the formation of a complex between starch and iodine results in a decrease in color and an increase of the SERS signal. The combined HS-PAD strategy allows an efficient separation and preconcentration of $\mathrm{SO}_{2}$. Concentrations of 5 and $1 \mu \mathrm{M}$ can be detected by the naked eye and SERS.

A dual PAD was described by the authors [106] for the simultaneous detection of nitrite and sulphide in waters. For this, a PAD containing two separate sections drawn with a permanent marker was built. The probes, i.e., Griess reagent and $\mathrm{Cu}(\mathrm{II})$ solution, were deposited in each separate section of the PAD, which was placed in the screw cap of a $40 \mathrm{~mL}$ vial for headspace sampling. Selective volatilization reactions were implemented in the vial yielding nitrogen oxides and hydrogen sulphide from nitrite and sulphide, respectively. LODs of 5 and $28 \mathrm{ppb}$ were achieved for nitrite and suphide, respectively. The PAD integrated within headspace microextraction shows an improved sensitivity ( 8 and 124 enhancement for nitrite and sulphide, respectively) as compared to most PADs and microPADs described in the literature.

\section{Conclusions and Outlook}

Unlike analytical techniques available in central labs, paper-based analytical devices (PADs and microPADs) allow low sample and reagent consumption, portability, easy operation, and real time measurements. Thus, in the environmental field, these analytical systems can successfully meet several requirements, such as easy access to remote sites, preliminary evaluation of water quality, spatial and temporal variability of pollutants aimed at determining their sources, distribution, and environmental impact. On the other hand, there exists a demand for disposable sensors for field applications in resource-limited regions. The spread use of disposable sensors could facilitate to take actions in a fast way in order to assess contamination events in different socioeconomic contexts.

The current state of paper-based analytical devices in environmental analysis allows to conclude that although several works have been reported on detection of some transition (e.g., $\mathrm{Cu}, \mathrm{Ni}, \mathrm{Co}$, etc.) and heavy metals $(\mathrm{Hg}, \mathrm{Cd})$, there is a lack for other elements of high toxicity (e.g., As, Sb, Tl, Bi, etc.). The availability of PADs and microPADS for chemical speciation (e.g., valence states of $\mathrm{As}, \mathrm{Se}, \mathrm{Sb}$, etc.) is also practically null. In addition, scarce attention has been paid to toxic organometals of environmental relevance such as methyl- $\mathrm{Hg}$, tetraethyl- $\mathrm{Pb}$, organic-Mn, etc. Likewise, there is still a small number of assays based on PADs for the detection of anions (with exception of nitrite). As was mentioned 
previously, environmental applications have been limited to samples with simple matrix, but there is a lack of assays for samples with high contents in salts, organic matter, etc.

Finally, other shortcomings identified in this review include (i) difficulties of many PADs and microPADs to cope with the low concentration levels of relevant toxic elements (e.g., $\mathrm{Hg}$ ) in order to comply with international regulations for drinking water; (ii) almost absence of applications of PADs to the detection of trace metals in seawater; (iii) few assays available for multielemental analysis. Sensing approaches based on PADs with nanostructured receptors provide, in general, better analytical performance (sensitivity and LOD) as compared to traditional chromogenic/fluorogenic reagents. Implementation of nanomaterials with enhanced optical properties and integration of the cellulose-based sensing platforms with novel microseparation strategies could lead to opening up new avenues so as to expand the scope of paper-based sensors for trace element analysis and speciation in the environmental field. In this sense, characteristics such as sensitivity, selectivity, precision, multiplexing ability, robustness, and stability should be focused on and, therefore, new developments are expected in the future.

Author Contributions: Conceptualization, methodology, investigation, C.B.; writing-original draft preparation, C.B.; writing-review and editing, C.B., I.L., F.P.-P., I.d.l.C., V.R.; visualization and supervision, C.B., I.L., F.P.-P., I.d.l.C., V.R. All authors have read and agreed to the published version of the manuscript.

Funding: This research was funded by the Spanish Ministry of Science, Innovation and Universities (Project RTI2018-093697-B-I00), the Spanish State Research Agency and FEDER.

Institutional Review Board Statement: Not applicable.

Informed Consent Statement: Not applicable.

Data Availability Statement: No new data were created or analyzed in this study. Data sharing is not applicable to this article.

Acknowledgments: V. Romero acknowledges the Xunta de Galicia for financial support as a postdoctoral researcher of the I2C program (ED481B 2017/033). F. Pena-Pereira thanks Xunta de Galicia (ED431I 2020/04) for financial support. I. de la Calle thanks University of Vigo for financial support as a distinguished post-doctoral researcher (European Social Funding P.P0000421S 140.08).

Conflicts of Interest: The authors declare no conflict of interest.

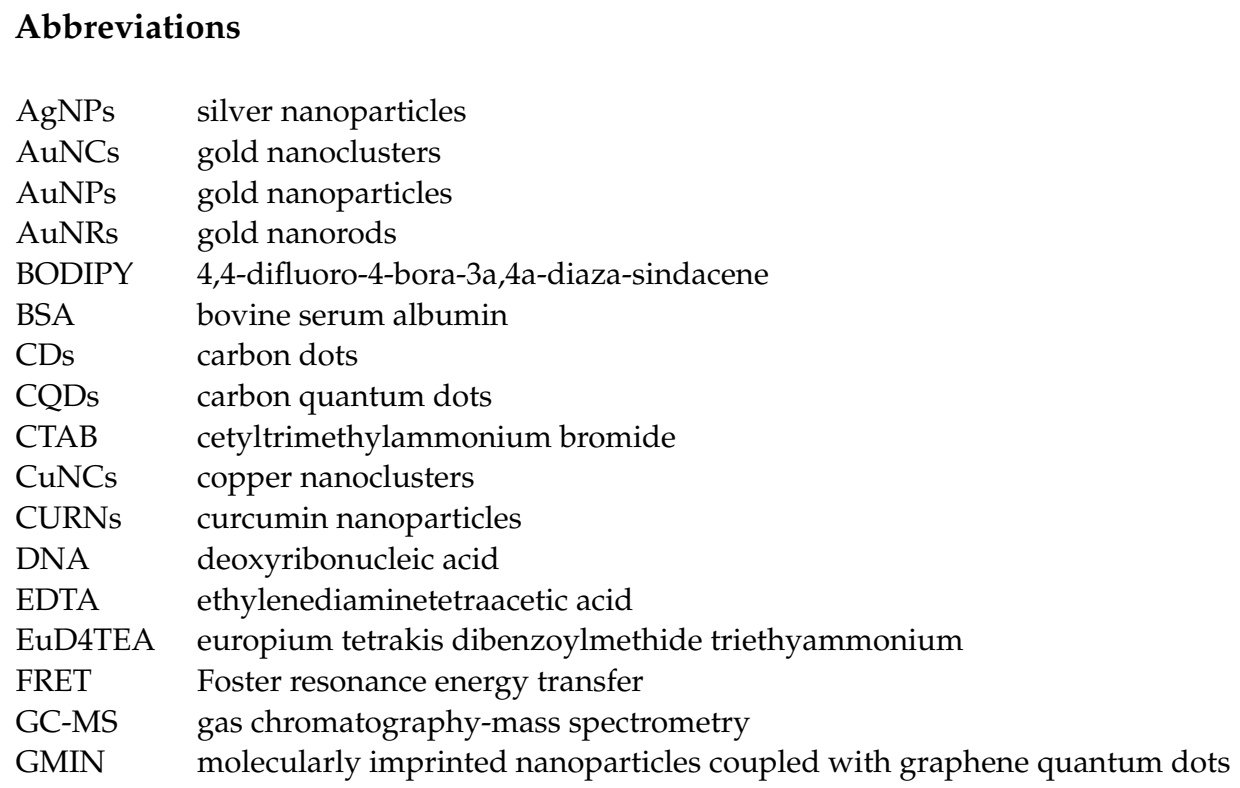




$\begin{array}{ll}\text { GQD } & \text { graphene quantum dots } \\ \text { HDTC } & \text { 2-hydroxyethyldithiocarbamate } \\ \text { HS } & \text { headspace } \\ \text { ICP-MS } & \text { inductively coupled plasma-mass spectrometry } \\ \text { LOD } & \text { limit of detection } \\ \text { LSPR } & \text { localized surface plasmon resonance } \\ \text { NCs } & \text { nanoclusters } \\ \text { NPs } & \text { nanoparticles } \\ \text { NRs } & \text { nanorods } \\ \text { PADs } & \text { paper-based assay devices } \\ \text { microPADs } & \text { microfluidic paper-based devices } \\ \text { PAR } & \text { 4-(2-pyridylazo) resorcinol } \\ \text { PDMS } & \text { polydimethylxilosane } \\ \text { PdNPs } & \text { palladium nanoparticles } \\ \text { PtNPs } & \text { platinum nanoparticles } \\ \text { QDs } & \text { quantum dots } \\ \text { RSD } & \text { relative standard deviation } \\ \text { RSNO } & \text { S-nitrosothiol } \\ \text { SDME } & \text { single-drop microextraction } \\ \text { SERS } & \text { surface-enhanced Raman scattering } \\ \text { SH-CAT } & \text { superhydrofobic chemical-responsive adhesive tape } \\ \text { SNAP } & \text { S-Nitroso-N-acetylpenicillamine } \\ \text { SPE } & \text { solid-phase extraction } \\ \text { SPME } & \text { solid-phase microextraction } \\ \text { SPR } & \text { surface plasmon resonance } \\ \text { STCP } & \text { silanization-titanium dioxide modified filter paper } \\ \text { SsDNA } & \text { single strand DNA } \\ \text { TAS } & \text { total analysis systems } \\ \text { TA-DNS } & \text { thioctic acid-dansylhydrazine } \\ \text { TBT } & \text { tributhyltin } \\ \text { TFME } & \text { thin-film microextraction } \\ \text { TICs } & \text { information and communication technologies } \\ \text { TMB } & \text { 3,3,5,5-tetramethylbenzidine } \\ \text { US EPA } & \text { United States Environmental Protection Agency } \\ \text { WHO } & \text { World Health Organization } \\ & \end{array}$

\section{References}

1. Pena-Pereira, F.; Bendicho, C.; Mutavdžić Pavlović, D.; Martin-Esteban, A.; Diaz-Alvarez, M.; Pan, Y.; Cooper, J.; Yang, Z.; Safarik, I.; Pospiskova, K.; et al. Miniaturized analytical methods for determination of environmental contaminants of emerging concern. A Review. Anal. Chim. Acta 2020, in press. [CrossRef]

2. Pol, R.; Céspedes, F.; Gabriel, D.; Baeza, M. Microfluidic lab-on-a-chip platforms for environmental monitoring. Trends Anal. Chem. 2017, 95, 62-68. [CrossRef]

3. Pena-Pereira, F.; Duarte, R.M.B.O.; Duarte, A.C. Immobilization strategies and analytical applications for metallic and metal-oxide nanomaterials on surfaces. Trends Anal. Chem. 2012, 40, 90-105. [CrossRef]

4. Martinez, A.W.; Phillips, S.T.; Whitesides, G.M.; Carrilho, E. Diagnostics for the developing world: Microfluidic paper-based analytical devices. Anal. Chem. 2010, 82, 3-10. [CrossRef]

5. Borjesson, M.B.; Westman, G. Crystalline nanocellulose-Preparation, modification and properties. In Cellulose-Fundamental Aspects and Current Trends; Poletto, M., Ornaghi Junio, H.L., Eds.; IntechOpen: London, UK, 2015; pp. 159-191. ISBN 978-953-51-2229-6.

6. Shaghaleh, H.; Xu, X.; Wang, S. Current progress in production of biopolymeric materials based on cellulose, cellulose nanofibers and cellulose derivatives. RSC Adv. 2018, 8, 825-842. [CrossRef]

7. Jensen, W.B. Remembering qualitative analysis. Educ. Química 2017, 28, 217-224. [CrossRef]

8. Bendicho, C.; Lavilla, I. Water analysis: Sewage. In Encyclopedia of Analytical Sciences, 3rd ed.; Worsfold, P., Townshend, A., Poole, C., Miró, M., Eds.; Academic Press: Cambridge, MA, USA, 2019; pp. 371-381, ISBN 9780081019849.

9. USEPA, National Primary Drinking Water Regulations. Available online: https:/ /www.epa.gov/ground-water-and-drinkingwater/national-primary-drinking-water-regulations\#Inorganic (accessed on 3 December 2020).

10. World Health Organization. Guidelines for Drinking-Water Quality, 4th ed.; 1st Addendum; World Health Organization: Geneva, Switzerland, 1993. Available online: https:/ / www.who.int/publications/i/item/9789241550017 (accessed on 3 December 2020).

11. Council Directive 98/83/EC of 3 November 1998 on the quality of water intended for human consumption. Off. J. Eur. Communities $1998,41, \mathrm{~L} 330 / 32-54$. 
12. López-Marzo, A.M.; Mercoçi, A. Paper-based sensors and assays: A success of the engineering design and the convergence of knowledge areas. Lab Chip 2016, 16, 3150-3176. [CrossRef]

13. Almeida, M.I.G.S.; Jayawardane, B.M.; Kolev, S.D.; McKelvie, I.D. Developments of microfluidic paper-based analytical devices ( $\mu$ PADs) for water analysis: A review. Talanta 2018, 177, 176-190. [CrossRef]

14. Meredith, N.A.; Quinn, C.; Cate, D.M.; Reilly, T.H., III; Volkens, J.; Henry, C.S. Paper-based analytical devices for environmental analysis. Analyst 2016, 141, 1874-1887. [CrossRef]

15. Aydindogan, E.; Celik, E.G.; Timur, S. Paper-based analytical methods for smartphone sensing with functional nanoparticles: Bridges from smart surfaces to global health. Anal. Chem. 2018, 90, 12325-12333. [CrossRef] [PubMed]

16. Yang, Y.; Noviana, E.; Nguyen, M.P.; Geiss, B.J.; Dandy, D.S.; Henry, C.S. Paper-based microfluidic devices: Emerging themes and applications. Anal. Chem. 2017, 89, 71-91. [CrossRef] [PubMed]

17. Nery, E.W.; Kubota, L.T. Sensing approaches on paper-based devices: A review. Anal. Bioanal. Chem. 2013, 405, 7573-7595. [CrossRef] [PubMed]

18. Liana, D.D.; Raguse, B.; Gooding, J.J.; Chow, E. Recent advances in paper-based sensors. Sensors 2012, 12, 11505-11526. [CrossRef]

19. Kaneta, T.; Alahmad, W.; Varanusupakul, P. Microfluidic paper-based analytical devices with instrument free detection and miniaturized portable detectors, Applied spectroscopy reviews. Appl. Spectrosc. Rev. 2019, 54, 117-141. [CrossRef]

20. Carrilho, Technical aspects and challenges of colorimetric detection with microfluidic paper-based analytical devices ( $\mu$ PADs) $-\mathrm{A}$ review. Anal. Chim. Acta 2017, 970, 1-22. [CrossRef]

21. Cate, D.M.; Adkins, J.A.; Mettakoonpitak, J.; Henry, C.S. Recent developments in paper-based microfluidic devices. Anal. Chem. 2015, 87, 19-41. [CrossRef]

22. Li, Y.; Chen, Y.; Yu, H.; Tian, L.; Wang, Z. Portable and smart devices for monitoring heavy metal ions integrated with nanomaterials. TrAC, Trends Anal. Chem. 2018, 98, 190-200. [CrossRef]

23. Ullah, N.; Mansha, M.; Khan, I.; Qurashi, A. Nanomaterial-based optical chemical sensors for the detection of heavy metals in water: Recent advances and challenges. TrAC, Trends Anal. Chem. 2018, 100, 155-166. [CrossRef]

24. Sriram, G.; Bhat, M.P.; Patil, P.; Uthappa, U.T.; Jung, H.-Y.; Altalhi, T.; Kumeria, T.; Aminabhavi, T.M.; Pai, R.K.; Kurkuri, M.D. Paper-based microfluidic analytical devices for colorimetric detection of toxic ions: A review. TrAC, Trends Anal. Chem. 2017, 93, 212-227. [CrossRef]

25. Kang, S.-M.; Jang, S.-C.; Haldorai, Y.; Vilian, A.T.E.; Rethinasabapathy, M.; Roh, C.; Han, Y.-K.; Huh, Y.S. Facile fabrication of paper-based analytical devices for rapid and highly selective colorimetric detection of cesium in environmental samples. RSC Adv. 2017, 7, 48374-48385. [CrossRef]

26. Pratiwi, R.; Nguyen, M.P.; Ibrahim, S.; Yoshioka, N.; Henry, C.S.; Tjahjono, D.H. A selective distance-based paper analytical device for copper(II) determination using a porphyrin derivative. Talanta 2017, 174, 493-499. [CrossRef] [PubMed]

27. Wang, H.; Li, Y.-J.; Wei, J.-F.; Xu, J.-r.; Wang, Y.-H.; Zheng, G.-X. Paper-based three-dimensional microfluidic device for monitoring of heavy metals with a camera cell phone. Anal. Bioanal. Chem. 2014, 406, 2799-2807. [CrossRef] [PubMed]

28. Rattanarat, P.; Dungchai, W.; Cate, D.M.; Siangproh, W.; Volckens, J.; Chailapakul, O.; Henry, C.S. A microfluidic paper-based analytical device for rapid quantification of particulate chromium. Anal. Chim. Acta 2013, 800, 50-55. [CrossRef]

29. Sun, X.; Li, B.; Qi, A.; Tian, C.; Han, J.; Shi, Y.; Lin, B.; Chen, L. Improved assessment of accuracy and performance using a rotational paper based device for multiplexed detection of heavy metals. Talanta 2018, 178, 426-431. [CrossRef]

30. Meredith, N.A.; Volckens, J.; Henry, C.S. Paper-based microfluidics for experimental design: Screening masking agents for simultaneous determination of Mn(II) and Co(II). Anal. Methods 2017, 9, 534-540. [CrossRef]

31. Cui, Y.; Wang, X.; Zhang, Q.; Zhang, H.; Li, H.; Meyerhoff, M. Colorimetric copper ion sensing in solution phase and on paper substrate based on catalytic decomposition of S-nitrosothiol. Anal. Chim. Acta 2019, 1053, 155-161. [CrossRef]

32. Hossain, S.M.Z.; Brennan, J.D. $\beta$-Galactosidase-based colorimetric paper sensor for determination of heavy metals. Anal. Chem. 2011, 83, 8772-8778. [CrossRef]

33. Cate, D.M.; Noblitt, S.D.; Volckens, J.; Henry, C.S. Multiplexed paper analytical device for quantification of metals using distance-based detection. Lab Chip 2015, 15, 2808-2818. [CrossRef]

34. Mentele, M.M.; Cunningham, J.; Koehler, K.; Volckens, J.; Henry, C.S. Microfluidic paper-based analytical device for particulate metals. Anal. Chem. 2012, 84, 4474-4480. [CrossRef]

35. Rattanarat, P.; Dungchai, W.; Cate, D.; Volckens, J.; Chailapakul, O.; Henry, C.S. Multilayer paper-based device for colorimetric and electrochemical quantification of metals. Anal. Chem. 2014, 86, 3555-3562. [CrossRef] [PubMed]

36. Hofstetter, J.C.; Wydallis, J.B.; Neymark, G.; Reilly, T.H., III; Harrington, T.; Henry, C.S. Quantitative colorimetric paper analytical devices based on radial distance measurements for aqueous metal determination. Analyst 2018, 143, 3085-3090. [CrossRef] [PubMed]

37. Quinn, C.W.; Cate, D.M.; Miller-Lionberg, D.D.; Reilly, T., III; Volckens, J.; Henry, C.S. Solid-phase extraction coupled to a paper-based technique for trace copper detection in drinking water. Environ. Sci. Technol. 2018, 52, 3567-3573. [CrossRef] [PubMed]

38. Sharifi, H.; Tashkhourian, J.; Hemmateenejad, B. A 3D origami paper-based analytical device combined with PVC membrane for colorimetric assay of heavy metal ions: Application to determination of $\mathrm{Cu}(\mathrm{II})$ in water samples. Anal. Chim. Acta 2020, 1126, 114-123. [CrossRef] [PubMed] 
39. Tan, W.; Aruna; Xu, Z.; Zhang, L.; Shen, W. Trace analysis on chromium (VI) in water by pre-concentration using a superhydrophobic surface and rapid sensing using a chemical-responsive adhesive tape. Talanta 2020, 218, 121116. [CrossRef]

40. Li, B.; Fu, L.; Zhang, W.; Feng, W.; Chen, L. Portable paper-based device for quantitative colorimetric assays relying on light reflectance principle. Electrophoresis 2014, 35, 1152-1159. [CrossRef] [PubMed]

41. Satarpai, T.; Shiowatana, J.; Siripinyanond, A. Paper-based analytical device for sampling, on-site preconcentration and detection of ppb lead in water. Talanta 2016, 154, 504-510. [CrossRef]

42. Xiong, X.; Zhang, J.; Wang, Z.; Liu, C.; Xiao, W.; Han, J.; Shi, Q. Simultaneous multiplexed detection of protein and metal ions by a colorimetric microfluidic paper-based analytical device. BioChip J. 2020, 14, 429-437. [CrossRef]

43. Ponram, M.; Balijapalli, U.; Sambath, B.; Iyer, S.K.; Kakaraparthi, K.; Thota, G.; Bakthavachalam, V.; Cingaram, R.; Sung-Ho, J.; Sundaramurthy, K.N. Inkjet-printed phosphorescent Iridium(III) complex based paper sensor for highly selective detection of $\mathrm{Hg}^{2+}$. Dyes Pigm. 2019, 163, 176-182. [CrossRef]

44. Pena-Pereira, F.; Velázquez, A.; Lavilla, I.; Bendicho, C. A paper-based colorimetric assay with non-instrumental detection for determination of boron in water samples. Talanta 2020, 208, 120365. [CrossRef]

45. Guo, J.; Huo, D.; Yang, M.; Hou, C.; Li, J.; Fa, H.; Luo, H.; Yang, P. Colorimetric detection of Cr(VI) based on the leaching of gold nanoparticles using a paper-based sensor. Talanta 2016, 161, 819-825. [CrossRef] [PubMed]

46. Ratnarathorn, N.; Chailapakul, O.; Henry, C.S.; Dungchai, W. Simple silver nanoparticle colorimetric sensing for copper by paper-based devices. Talanta 2012, 99, 552-557. [CrossRef] [PubMed]

47. Chen, G.H.; Chen, W.-Y.; Yen, Y.-C.; Wang, C.-W.; Chang, H.-T.; Chen, C.-F. Detection of mercury(II) ions using colorimetric gold nanoparticles on paper-based analytical devices. Anal. Chem. 2014, 86, 6843-6849. [CrossRef] [PubMed]

48. Chen, W.; Fang, X.; Li, H.; Cao, H.; Kong, J. A Simple paper-based colorimetric device for rapid mercury(II) assay. Sci. Rep. 2016, 3, 31948. [CrossRef] [PubMed]

49. Pourreza, N.; Golmohammadi, H.; Rastegarzadeh, S. Highly selective and portable chemosensor for mercury determination in water samples using curcumin nanoparticles in a paper based analytical device. RSC Adv. 2016, 6, 69060-69066. [CrossRef]

50. Ismail, M.; Khan, M.I.; Akhtar, K.; Seo, J.; Khan, A.K.; Asiri, A.M.; Khan, S.B. Phytosynthesis of silver nanoparticles; naked eye cellulose filter paper dual mechanism sensor for mercury ions and ammonia in aqueous solution. J. Mater. Sci.: Mater. Electron. 2019, 30, 7367-7383. [CrossRef]

51. Li, J.; Hou, C.; Huo, D.; Shen, C.; Luo, X.; Fa, H.; Yang, M.; Zhou, J. Detection of trace nickel ions with a colorimetric sensor based on indicator displacement mechanism. Sens. Actuators B 2017, 241, 1294-1302. [CrossRef]

52. Shrivas, K.; Kant, T.M.; Karbhal, I.; Kurrey, R.; Sahu, B.; Sinha, D.; Patra, G.K.; Deb, M.K.; Pervez, S. Smartphone coupled with paper-based chemical sensor for on-site determination of iron(III) in environmental and biological samples. Anal. Bioanal. Chem. 2020, 412, 1573-1583. [CrossRef]

53. Dong, R.-E.; Kang, P.; Xu, X.-L.; Cai, L.-X.; Guo, Z. Cation-exchange strategy for a colorimetric paper sensor: Belt-like ZnSe nanoframes toward visual determination of heavy metal ions. Sens. Actuators B 2020, 312, 128013. [CrossRef]

54. Nath, P.; Arun, R.K.; Chanda, N. Smart gold nanosensor for easy sensing of lead and copper ions in solution and using paper strips. RSC Adv. 2015, 5, 69024-69031. [CrossRef]

55. Sadollahkhani, A.; Hatamie, A.; Nur, O.; Willander, M.; Zargar, B.; Kazeminezhad, I. Colorimetric disposable paper coated with $\mathrm{ZnO} / \mathrm{ZnS}$ core-shell nanoparticles for detection of copper ions in aqueous solutions. ACS Appl. Mater. Interfaces 2014, 6 , 17694-17701. [CrossRef] [PubMed]

56. Jayawardane, B.M.; Wei, S.; McKelvie, I.D.; Kolev, S.D. Microfluidic paper-based analytical device for the determination of nitrite and nitrate. Anal. Chem. 2014, 86, 7274-7279. [CrossRef] [PubMed]

57. López-Ruiz, N.; Curto, V.F.; Erenas, M.M.; Benito-Lopez, F.; Diamond, D.; Palma, A.J.; Capitan-Vallvey, L.F. Smartphone-based simultaneous $\mathrm{pH}$ and nitrite colorimetric determination for paper microfluidic devices. Anal. Chem. 2014, 86, 9554-9562. [CrossRef] [PubMed]

58. Liu, Y.-C.; Hsu, C.-H.; Lu, B.-J.; Lin, P.-Y.; Ho, M.-L. Determination of nitrite ions in environment analysis with a paper-based microfluidic device. Dalton Trans. 2018, 47, 14799-14807. [CrossRef]

59. Ortiz-Gomez, I.; Ortega-Muñoz, M.; Salinas-Castillo, A.; Álvarez-Bermejo, J.A.; Ariza-Avidad, M.; de Orbe-Paya, I.; SantoyoGonzalez, F.; Capitan-Vallvey, L.F. Tetrazine-based chemistry for nitrite determination in a paper microfluidic device. Talanta 2016, 160, 721-728. [CrossRef]

60. Cardoso, T.M.G.; Garcia, P.T.; Coltro, W.K.T. Colorimetric determination of nitrite in clinical, food and environmental samples using microfluidic devices stamped in paper platforms. Anal. Methods 2015, 7, 7311-7317. [CrossRef]

61. Wu, X.; Wang, H.; Yang, S.; Tian, H.; Liu, Y.; Sun, B. Highly sensitive ratiometric fluorescent paper sensors for the detection of fluoride ions. ACS Omega 2019, 4, 4918-4926. [CrossRef]

62. Rull-Barrull, J.; d'Halluin, M.; Le Grognec, E.; Felpin, F.-X. Chemically-modified cellulose paper as smart sensor device for colorimetric and optical detection of hydrogen sulfate in water. Chem. Commun. 2016, 52, 2525-2528. [CrossRef]

63. Duangdeewong, C.; Sitanurak, J.; Wilairat, P.; Nacapricha, D.; Teerasong, S. Microfluidic paper-based analytical device for convenient use in measurement of iodate in table salt and irrigation water. Microchem. J. 2020, 152, 104447. [CrossRef]

64. Lert-itthiporn, A.; Srikritsadawong, P.; Choengchan, N. Foldable paper-based analytical device for membraneless gas-separation and determination of iodate based on fluorescence quenching of gold nanoclusters. Talanta 2021, 221, 121574. [CrossRef] 
65. Shahvar, A.; Saraji, M.; Gordan, H.; Shamsaei, D. Combination of paper-based thin film microextraction with smartphone based sensing for sulfite assay in food samples. Talanta 2019, 197, 578-583. [CrossRef] [PubMed]

66. Li, M.; Cushing, S.K.; Wu, N. Plasmon-enhanced optical sensors: A review. Analyst 2015, 140, 386-406. [CrossRef] [PubMed]

67. Wu, J.; Li, M.; Tang, H.; Su, J.; He, M.; Chen, G.; Guan, L.; Tian, J. Portable paper sensors for the detection of heavy metals based on light transmission-improved quantification of colorimetric assays. Analyst 2019, 144, 6382-6390. [CrossRef]

68. Phoonsawat, K.; Ratnarathorn, N.; Henry, C.S.; Dungchai, W. A distance-based paper sensor for the determination of chloride ions using silver nanoparticles. Analyst 2018, 143, 3867-3873. [CrossRef] [PubMed]

69. Costas-Mora, I.; Romero, V.; Lavilla, I.; Bendicho, C. An overview of recent advances in the application of quantum dots as luminescent probes to inorganic-trace analysis. TrAC Trends Anal. Chem. 2014, 57, 64-72. [CrossRef]

70. Dong, Y.; Cai, J.; You, X.; Chi, Y. Sensing applications of luminescent carbon-based dots. Analyst 2015, 140, 7468-7486. [CrossRef] [PubMed]

71. Zhang, L.; Wang, E. Metal nanoclusters: New fluorescent probes for sensors and bioimaging. Nano Today 2014, 9, 132-157. [CrossRef]

72. Huang, K.; Xu, K.; Zhu, W.; Yang, L.; Hou, X.; Zheng, C. Hydride generation for headspace solid-phase extraction with CdTe quantum dots immobilized on paper for sensitive visual detection of selenium. Anal. Chem. 2016, 88, 789-795. [CrossRef]

73. Xiao, M.; Liu, Z.; Xu, N.; Jiang, L.; Yang, M.; Yi, C. A Smartphone-based sensing system for on-site quantitation of multiple heavy metal ions using fluorescent carbon nanodots-based microarrays. ACS Sens. 2020, 5, 870-878. [CrossRef]

74. Anh, N.T.N.; Chowdhury, A.D.; Doong, R. Highly sensitive and selective detection of mercury ions using N,S-codoped graphene quantum dots and its paper strip based sensing application in wastewater. Sens. Actuators B 2017, 252, 1169-1178. [CrossRef]

75. Li, X.; Zheng, Y.; Tang, Y.; Chen, Q.; Gao, J.; Luo, Q.; Wang, Q. Efficient and visual monitoring of cerium(III) ions by greenfluorescent carbon dots and paper-based sensing. Spectrochim. Acta Part A 2019, 206, 240-245. [CrossRef] [PubMed]

76. Lu, F.; Zhou, Y.; Wu, L.; Qian, J.; Cao, S.; Deng, Y.; Chen, Y. Highly fluorescent nitrogen-doped graphene quantum dots' synthesis and their applications as Fe(III) ions sensor. Int. J. Opt. 2019, 2019, 8724320. [CrossRef]

77. Yuan, C.; Zhang, K.; Zhang, Z.; Wang, S. Highly selective and sensitive detection of mercuric ion based on a visual fluorescence method. Anal. Chem. 2012, 84, 9792-9801. [CrossRef] [PubMed]

78. Liu, Q.; Lin, Y.; Xiong, J.; Wu, L.; Hou, X.; Xu, K.; Zheng, C. Disposable paper-based analytical device for visual speciation analysis of $\operatorname{Ag}(\mathrm{I})$ and silver nanoparticles (AgNPs). Anal. Chem. 2019, 91, 3359-3366. [CrossRef]

79. Xiong, J.; Xu, K.; Hou, X.; Wu, P. AuNCs-catalyzed hydrogen selenide oxidation: Mechanism and application for headspace fluorescent detection of Se(IV). Anal. Chem. 2019, 91, 6141-6148. [CrossRef]

80. Kim, Y.; Jang, G.; Lee, T.S. New fluorescent metal-ion detection using a paper-based sensor strip containing tethered rhodamine carbon nanodots. ACS Appl. Mater. Interfaces 2015, 7, 15649-15657. [CrossRef]

81. Sari, E.; Üzek, R.; Merkoçi, A. Paper based photoluminescent sensing platform with recognition sites for tributyltin. ACS Sens. 2019, 4, 645-653. [CrossRef]

82. Yu, S.; Li, W.; Fujii, Y.; Omura, T.; Minami, H. Fluorescent spherical sponge cellulose sensors for highly selective and semiquantitative visual analysis: Detection of $\mathrm{Hg}^{2+}$ and $\mathrm{Cu}^{2+}$ ions. ACS Sustain. Chem. Eng. 2019, 7, 19157-19166. [CrossRef]

83. Wang, Y.; Zhang, C.; Chen, X.; Yang, B.; Yang, L.; Jiang, C.; Zhang, Z. Ratiometric fluorescent paper sensor utilizing carbon dots-quantum dots for the visual determination of copper ions. Nanoscale 2016, 8, 5977-5984. [CrossRef]

84. Li, J.; Li, P.; Bian, M.; Huo, D.; Hou, C.; Qin, H.; Zhang, S.; Zhang, L. A Fluorescent detection method for copper ions, based on a direct redox route and desk study of wax-printed paper-based probes. Anal. Methods 2018, 10, 1895-1901. [CrossRef]

85. Patir, K.; Gogoi, S.K. Nitrogen-doped carbon dots as fluorescence ON-OFF-ON sensor for parallel detection of copper(II) and mercury(II) ions in solutions as well as in filter paper-based microfluidic device. Nanoscale Adv. 2019, 1, 592-601. [CrossRef]

86. Yu, L.; Qu, Y.; Chai, F.; Chen, L. Facile preparation of highly sensitive and selective fluorescent paper sensor for the visual and cyclic detection of $\mathrm{Cu}^{2+}$ and $\mathrm{Hg}^{2+}$. New J. Chem. 2018, 42, 17478-17485. [CrossRef]

87. Huang, K.; Dai, R.; Deng, W.; Guo, S.; Deng, H.; Wei, Y.; Zhou, F.; Long, Y.; Li, J.; Yuand, X.; et al. Gold nanoclusters immobilized paper for visual detection of zinc in whole blood and cells by coupling hydride generation with headspace solid phase extraction. Sens. Actuators B 2018, 255, 1631-1639. [CrossRef]

88. Liu, X.; Yang, Y.; Li, Q.; Wang, Z.; Xing, X.; Wang, Y. Portably colorimetric paper sensor based on ZnS quantum dots for semi-quantitative detection of $\mathrm{Co}^{2+}$ through the measurement of grey level. Sens. Actuators B 2018, 260, 1068-1075. [CrossRef]

89. Liu, X.; Yang, Y.; Xing, X.; Wang, Y. Grey level replaces fluorescent intensity: Fluorescent paper sensor based on ZnO nanoparticles for quantitative detection of $\mathrm{Cu}^{2+}$ without photoluminescence spectrometer. Sens. Actuators B 2018, 255, 2356-2366. [CrossRef]

90. Wang, Y.; Yang, L.; Liu, B.; Yu, S.; Jiang, C. A colorimetric paper sensor for visual detection of mercury ions constructed with dual-emission carbon dots. New J. Chem. 2018, 42, 15671-15677. [CrossRef]

91. Gao, Y.; Jiao, Y.; Zhang, H.; Lu, W.; Liu, Y.; Han, H.; Gong, X.; Li, L.; Shuang, S.; Dong, C. One-step synthesis of a dual-emitting carbon dot-based ratiometric fluorescent probe for the visual assay of $\mathrm{Pb}^{2+}$ and $\mathrm{PPi}$ and development of a paper sensor. J. Mater. Chem. B 2019, 7, 5502-5509. [CrossRef]

92. Wang, H.; Yang, L.; Chu, S.; Liu, B.; Zhang, Q.; Zou, L.; Yu, S.; Jiang, C. Semiquantitative visual detection of lead ions with a smartphone via a colorimetric paper-based analytical device. Anal. Chem. 2019, 91, 9292-9299. [CrossRef]

93. Pena-Pereira, F.; Villar-Blanco, L.; Lavilla, I.; Bendicho, C. Test for arsenic speciation in waters based on a paper-based analytical device with scanometric detection. Anal. Chim. Acta 2018, 1011, 1-10. [CrossRef] 
94. Khatha, P.; Phutthaphongloet, T.; Timpa, P.; Ninwong, B.; Income, K.; Ratnarathorn, N.; Dungchai, W. Distance-based paper device combined with headspace extraction for determination of cyanide. Sensors 2019, 19, 2340. [CrossRef]

95. İncela, A.; Akın, O.; Çağır, A.; Yıldız, Ü.H.; Demir, M.M. Smart phone assisted detection and quantification of cyanide in drinking water by paper based sensing platform. Sens. Actuators B 2017, 252, 886-893. [CrossRef]

96. Nguyen, M.P.; Meredith, N.A.; Kelly, S.P.; Henry, C.S. Design considerations for reducing sample loss in microfluidic paper-based analytical devices. Anal. Chim. Acta 2018, 1017, 20-25. [CrossRef] [PubMed]

97. Feng, L.; Li, X.; Yang, W.; Chen, L.; Guan, Y. Enhancement of sensitivity of paper-based sensor array for the identification of heavy-metal ions. Anal. Chim. Acta 2013, 780, 74-80. [CrossRef] [PubMed]

98. Jarujambus, P.; Meelapsom, R.; Pencharee, S.; Obma, A.; Amatatongchai, M.; Ditcharoen, N.; Chairam, S.; Tamuang, S. Use of a smartphone as a colorimetric analyzer in paper-based devices for sensitive and selective determination of mercury in water samples. Anal. Sci. 2018, 34, 75-81. [CrossRef] [PubMed]

99. Wu, J.-H.; He, C.-Y. Advances in cellulose-based sorbents for extraction of pollutants in environmental samples. Chromatographia 2019, 82, 1151-1169. [CrossRef]

100. de la Calle, I.; Lavilla, I.; Bartolome-Alonso, H.; Bendicho, C. Solid-phase extraction of $\mathrm{Hg}(\mathrm{II})$ using cellulose filters modified with silver nanoparticles followed by pyrolysis and detection by a direct mercury analyzer. Spectrochim. Acta Part B 2019, 161, 105697. [CrossRef]

101. Zhang, Y.; Li, H.; Niu, L.-Y.; Yang, Q.-Z.; Guan, Y.-F.; Feng, L. An SPE-assisted BODIPY fluorometric paper sensor for the highly selective and sensitive determination of $\mathrm{Cd}^{2+}$ in complex sample: Rice. Analyst 2014, 139, 3146-3153. [CrossRef]

102. Bagheri, N.; Saraji, M. Combining gold nanoparticle-based headspace single-drop microextraction and a paper-based colorimetric assay for selenium determination. Anal. Bioanal. Chem. 2019, 411, 7441-7449. [CrossRef]

103. Pena-Pereira, F.; Capón, N.; de la Calle, I.; Lavilla, I.; Bendicho, C. Fluorescent poly(vinylpyrrolidone)-supported copper nanoclusters in miniaturized analytical systems for iodine sensing. Sens. Actuators B 2019, 299, 126979. [CrossRef]

104. Saraji, M.; Bagheri, N. Paper-based headspace extraction combined with digital image analysis for trace determination of cyanide in water samples. Sens. Actuators B 2018, 270, 28-34. [CrossRef]

105. Li, D.; Duan, H.; Ma, Y.; Deng, W. Headspace-sampling paper-based analytical device for colorimetric/surface-enhanced raman scattering dual sensing of sulfur dioxide in wine. Anal. Chem. 2018, 90, 5719-5727. [CrossRef] [PubMed]

106. Pena-Pereira, F.; Matesanz, O.; Lavilla, I.; Bendicho, C. A paper-based gas sensor for simultaneous non-instrumental colorimetric detection of nitrite and sulfide in waters. J. Sep. Sci. 2020, 43, 1908-1914. [CrossRef] [PubMed] 